\title{
Review Article \\ Curcumin: A Potential Candidate in Prevention of Cancer via Modulation of Molecular Pathways
}

\author{
Arshad H. Rahmani, ${ }^{1}$ Mohammad A. Al Zohairy, ${ }^{1}$ Salah M. Aly, ${ }^{1,2}$ and Masood A. Khan ${ }^{3}$ \\ ${ }^{1}$ Department of Medical Laboratories, College of Applied Medical Sciences, Qassim University, Buraida, Saudi Arabia \\ ${ }^{2}$ Department of Pathology, Faculty of Vet. Medicine, Suez Canal University, Ismailia, Egypt \\ ${ }^{3}$ Department of Basic Health Science, College of Applied Medical Sciences, Qassim University, Saudi Arabia
}

Correspondence should be addressed to Arshad H. Rahmani; rehmani.arshad@gmail.com

Received 19 June 2014; Revised 25 August 2014; Accepted 25 August 2014; Published 10 September 2014

Academic Editor: Goutam Ghosh Choudhury

Copyright (C) 2014 Arshad H. Rahmani et al. This is an open access article distributed under the Creative Commons Attribution License, which permits unrestricted use, distribution, and reproduction in any medium, provided the original work is properly cited.

\begin{abstract}
Cancer is the most dreadful disease worldwide in terms of morbidity and mortality. The exact cause of cancer development and progression is not fully known. But it is thought that cancer occurs due to the structural and functional changes in the genes. The current approach to cancer treatment based on allopathic is expensive, exhibits side effects; and may also alter the normal functioning of genes. Thus, a safe and effective mode of treatment is needed to control the cancer development and progression. Some medicinal plants provide a safe, effective and affordable remedy to control the progression of malignant cells. The importance of medicinal plants and their constituents has been documented in Ayurveda, Unani medicine, and various religious books. Curcumin, a vital constituent of the spice turmeric, is an alternative approach in the prevention of cancer. Earlier studies have shown the effect of curcumin as an antioxidant, antibacterial, antitumor and it also has a noteworthy role in the control of different diseases. In this review, we summarize the understanding of chemopreventive effects of curcumin in the prevention of cancer via the regulation of various cell signaling and genetic pathways.
\end{abstract}

\section{Introduction}

Population growth and aging may contribute to a dramatic increase in the numbers of cancer cases. The exact cause of the cancer development and progression is still not well known. But it is thought to be as a result from alterations in the various genetic [1-3] and metabolic pathways. The present regime to cancer treatment, based on synthetic drugs and chemotherapy/radiotherapy, is expensive and also alters the various mechanisms of the normal actions of genes. Presently, several medicinal plants and their constituents are in use to manage the development and progression of various diseases and have been found effective, safe, and less expensive. The importance of medicinal plants has been discussed in different religious books including Christianity, Hinduism, and Islam. Our Prophet Mohammad (PBUH) used and recommended various plants and their products in the cure of diseases $[4,5]$. In the present scenario, various parts of the world are using different types of local plants or products like turmeric in Indian cuisine and oregano in Italy, olive in Spain, and Ajwa dates in Saudi Arabia in the treatment and prevention of various diseases. Earlier studies have reported that olive, dates, and black seed show role in cancer prevention through modulation of various activities [6-8].

Curcumin is a polyphenolic compound derived from the popular Indian spice turmeric plant. It is a member of the Zingiberaceae (ginger) family, which is native to Southeast Asia [9], chemical structure was characterized in 1910 by Milobedeska and colleagues, and synthesis was confirmed by Lampe and colleagues in 1913 [10, 11]. Curcumin is lipophilic in nature which shows low solubility and stability in aqueous solution. It is extensively used in Ayurveda, Unani, Siddha, and Chinese medicine for the management of various diseases such as wound, inflammation, and cancer (Figure 1) and used in curries and dishes especially in spicy dishes in India, Pakistan, Bangladesh, and other countries of Asia. Curcumin, because of its special properties such 


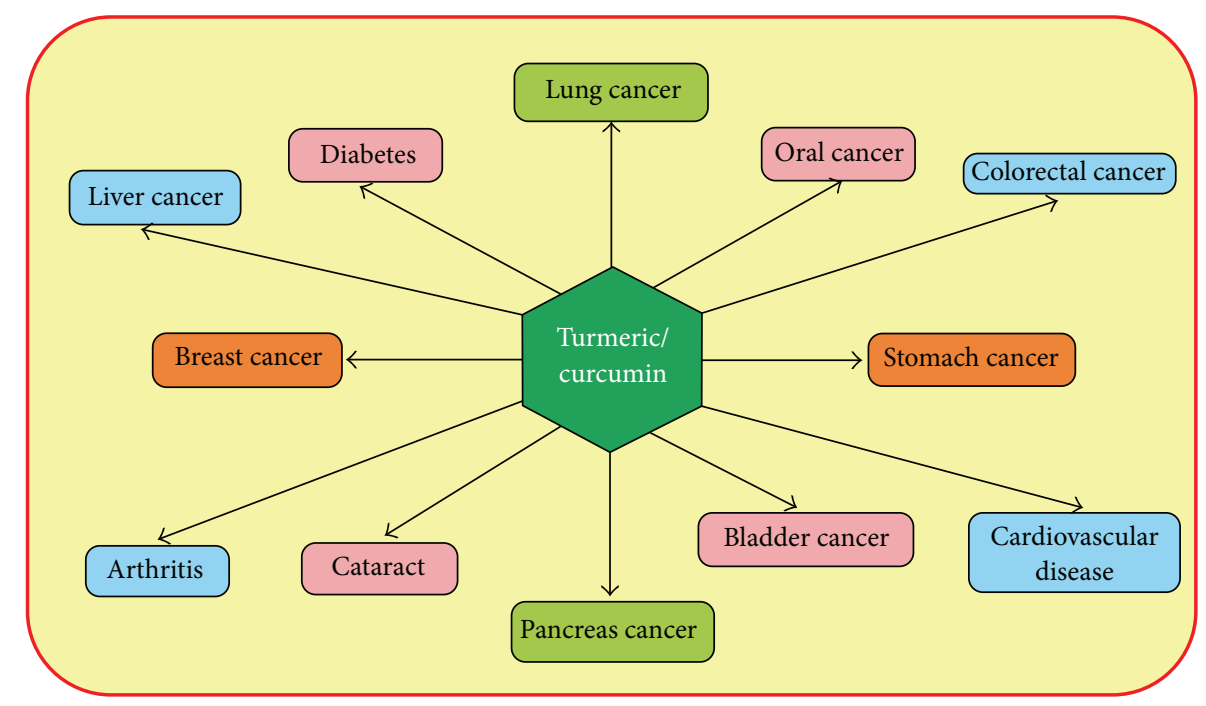

FIGURE 1: Turmeric/curcumin shows pivotal role in the prevention of diseases including cancer.

as being antiprotozoal and antioxidant and this uniqueness, might have a significant effect on several types of diseases anticipation [12, 13]. Important reviews based on curcumin provide an overview of the history, chemistry, analogs, and mechanism of action of curcumin [14] and another study discussed in detail the therapeutic implications of curcumin in patients with pancreatic cancer [15].

\section{Curcumin: Modulator of Molecular Pathways}

Tumorigenesis and tumor progression are thought to be as a result of some changes in the different types of genetic pathways $[16,17]$. Curcumin, chief constituents of turmeric, shows a vital role in cancer prevention and treatment through modulation of various biological activities including molecular cascades. However, understanding the turmeric's mechanism of action in the activation or inactivation of genetic pathways will provide significant information to develop therapeutic approaches to manage various types of cancers.

2.1. Effect of Curcumin on Tumor Suppressor Genes. Tumor suppressor genes play a vital and significant role in the inhibition of cancer formation and its progression. When an alteration or mutation occurs in a gene, then tumor suppressor gene lost its ability to perform normal function. Tumor suppressor gene p53 is the guardian of all genes and regulates the various cellular and molecular pathways and prevents cancer formation. Numerous in vivo and in vitro reports showed that turmeric and its constituents have a significant role in cancer prevention or inhibition. An important study showed that curcumin down-regulates the expression of p53, as well as the survival genes egr-1, cmyc and bcl-XL in B cells [18]. Another report has also indicated that curcumin inhibits cell cycle progression of immortalized human umbilical vein endothelial cells via upregulating the CDK inhibitors p21WAF1/CIP1, p27KIP1, and p53 [19]. Further studies reported that curcumin mainly acts in p53-dependent manner and also showed that wild p53 was highly susceptible to curcumin toxicity [20].

Another tumor suppressor gene, phosphatase and tensin homolog deleted on chromosome ten (PTEN) has a role in the progression of the cell cycle and apoptosis. The alteration or mutation of PTEN gene has been noticed in several types of cancers. A study of the curcumin has shown that PTEN increases the curcumin-induced apoptosis, whereas inactive PTEN decreases/inhibits the curcumin-induced apoptosis [21]. A study showed that difluorinated curcumin (CDF), a nontoxic analog, modulates the expression of miR-21 and PTEN in pancreatic cancer [22-25].

The retinoblastoma is a type of tumour suppressor gene and shows an important role in the control of cell cycle. $\mathrm{pRb}$, the protein coded for by the $R B 1$ gene, shows an important role in cell cycle regulation, promoting G1/S arrest and growth restriction via inhibition of the $\mathrm{E} 2 \mathrm{~F}$ transcription factors [26]. It is inactivated through hyperphosphorylation catalyzed by the cyclin D-cyclin-dependent kinase 4 (cyclin D-cdk4) and cyclin E-cdk2 complexes [27-29]. Various medicinal plants and their constituents show a vital role in the regulation of $\mathrm{Rb}$ genes via regulation of phophorylation. In this vista, curcumin, chief constituents of turmeric also shows an important role in modulation of $\mathrm{Rb}$ gene via reduction in hyperphosphorylation. An important study based on prostate cancer cells has revealed that curcumin induced the expression of cyclin-dependent kinase (CDK) inhibitors p16, p21, and p27 and inhibited the expression of cyclin E and cyclin D1 and hyperphosphorylation of retinoblastoma (Rb) protein [30] and another study has shown that suppression of cyclin D1 by curcumin led to inhibition of CDK4-mediated phosphorylation of retinoblastoma protein [31].

2.2. Effect of Curcumin on Apoptotic Genes. Apoptosis is one of the prerequisites to maintain the normal and healthy internal milieu. Any alteration or change in the normal process of apoptosis may increase cell survival and support the tumor 
development and progression $[32,33]$. Curcumin plays a vital role in the upregulation of different proapoptotic genes and at the same time downregulates some of the antiapoptotic genes and by this way balances the apoptosis process (Figure 2). An interesting study showed that curcumin induces apoptosis in scleroderma lung fibroblasts (SLF) without affecting normal lung fibroblasts [34]. Furthermore, curcumin has shown an antitumor activity and was involved in the apoptosis induction and the modulation of key apoptotic proteins such as Bax and bcl-2 [35]. A study has reported that growth arrest and apoptosis of B cell lymphoma occur through the down regulation of c-myc, bcl-XL, and p53 with the treatment of curcumin [36]. Another report in human breast cancer cell line showed that CD437 induces G0-G1 arrest and apoptosis via regulation of p21WAFI/CIPI, Bcl-2, and Bax in a p53 independent manner [37]. Another study on p53-null cells, as well as TR9-7 cells, reported that curcumin induces apoptosis in tumor cells via a p53-dependent pathway and Bax act as downstream effectors of p53 [38].

Curcumin induces apoptosis in a range of tumor cell lines through activation of caspase- 3 , cytochrome $c$ release, and downregulation of bcl-2 [39-42]. Curcumin has shown an apoptotic effect by inhibiting various genes such as protein tyrosine kinase, protein kinase $\mathrm{C}, \mathrm{c}-\mathrm{myc}$ mRNA expression, and bcl-2 mRNA expression [43] and also mitochondrial pathway. Earlier studies have shown that curcumin possesses an apoptotic activity in different types of cancer cell such as human colon cancer cells, stomach, and skin tumors, breast cancer cells, and prostate cancer cells [44-47]. Study of colon cancer cell line showed that apoptosis was increased in response to curcumin [48, 49]. Curcumin also showed a vital role in decreasing cell proliferation in a dose dependent manner [48-50]. Curcumin may lower the incidence of various cancers, including urothelial malignancies [51, 52] and also may induce apoptosis in MBT-2 cells [53] and G2/M arrest of T24 cells [54]. Experimental studies showed that the downregulation of the expression of antiapoptotic protein occurs with curcumin treatment $[55,56]$.

2.3. Effect of Curcumin on Angiogenesis. Angiogenesis is a complex process involving widespread interaction between the cells, soluble factors, and ECM components [57]. It also shows a vital effect in tumor growth and is triggered by chemical signals from tumor cells in a phase of rapid growth [58]. There are several angiogenic factors such as vascular endothelial growth factor (VEGF), basic fibroblast growth factor (bFGF), angiogenin, transforming growth factor (TGF- $\alpha$, TGF- $\beta$ ), and epidermal growth factor. These factors show a critical role in tumor angiogenesis via cancerous tumor cells by releasing molecules and sending signals to surrounding normal host tissue [59]. VEGF is a crucial survival factor for endothelial cells in the process of physiological, tumor angiogenesis and induces the expression of antiapoptotic proteins in the endothelial cells [60]. There are certain drugs, like Bevacizumab (Avastin), available as an inhibitor of VEGF action in the treatment of cancer. These drugs are expensive and a large group of the population cannot afford their cost. However, a safe and affordable natural product is needed to control the cancer development.
Earlier studies have shown that curcumin is an inhibitor of VEGF in different types of cancer, including orthotopically implanted pancreatic tumors [61]. Important record via in vitro and in vivo studies showed that curcumin suppresses the proliferation of human vascular endothelial cells and also abrogates the FGF-2-induced angiogenic response [62, 63]. Moreover, curcumin has the ability to inhibit both VEGF and its receptor in various cancer types; it might be useful as an antiangiogenic agent $[64,65]$. Besides, curcumin plays a major role in the suppression of transcriptional activity of AP62 and HIF-1 and causes a reduction in the expression of VEGF [66]. An important study results suggested that curcumin potentiates the antitumor effects of gemcitabine in pancreatic cancer via suppressing proliferation, angiogenesis, NF- $\kappa \mathrm{B}$, and NF- $\kappa \mathrm{B}$-regulated gene products [61]. A study of adenoid cystic carcinoma cells showed that curcumin significantly inhibited the growth, survival, migration/invasion, and downregulates VEGF and MMP-2/9 or inhibits the mTOR and NF- $\kappa$ B pathways [67].

\subsection{Effect of Curcumin on Phase I and Phase II Genes/} Enzymes. Xenobiotics are molecules introduced into the body from the environment and not produced inside the body. The body then metabolizes them through two phases of transformation: Phase I and Phase II.

The turmeric has shown a significant effect on the regulation of xenobiotic metabolism via inhibition of the phase I and activates the phase II gene/enzymes. In the phase I reactions, addition of a functional polar group normally results in a relatively small increase in hydrophilicity and may cause metabolic activation. Cytochrome P450 (CYP) is the main enzymes in phase I and shows the vital effect on the activation of carcinogens. So, control of CYP450 activity is the main issue in cancer prevention through increasing the degree of cellular safety. A study in rat model showed that curcumin inhibits the alkylation reaction catalyzed by CYP1A1, 1A2 [68]. In another interesting study, it was reported that CYP plays a vital role in the formation of aflatoxine-DNA adduct and this intermediate product is suppressed or inhibited by curcumin treatment [69]. Curcumin has shown its effect in hampering CYP1A1 activity in DMBA-treated cells and also inhibited the metabolic activation of DMBA and decreased the DMBA-induced cytotoxicity [70].

In the Phase II reactions, conjugation with a small hydrophilic endogenous substance increases the hydrophilicity and facilitates the emission. However, the activation of Phase II enzymes such as Glutathione S Transferase in the treatment and suppression of cancer is critical and is a significant strategy. Several earlier studies reported that turmeric and its constituents play a significant role in the prevention of cancer via the activation of GST genes.

An important finding showed that turmeric/curcumin enhances the activity of Phase II enzyme GST [71-76]. Curcumin also elevates the protein as well as mRNA expressions of GSTs and NQO1 in mouse tissues, suggesting a role of curcumin in transcriptional regulation of phase II enzymes [77]. Moreover, curcumin induces GST expression by signalling through the nuclear erythroid-derived 2-related 


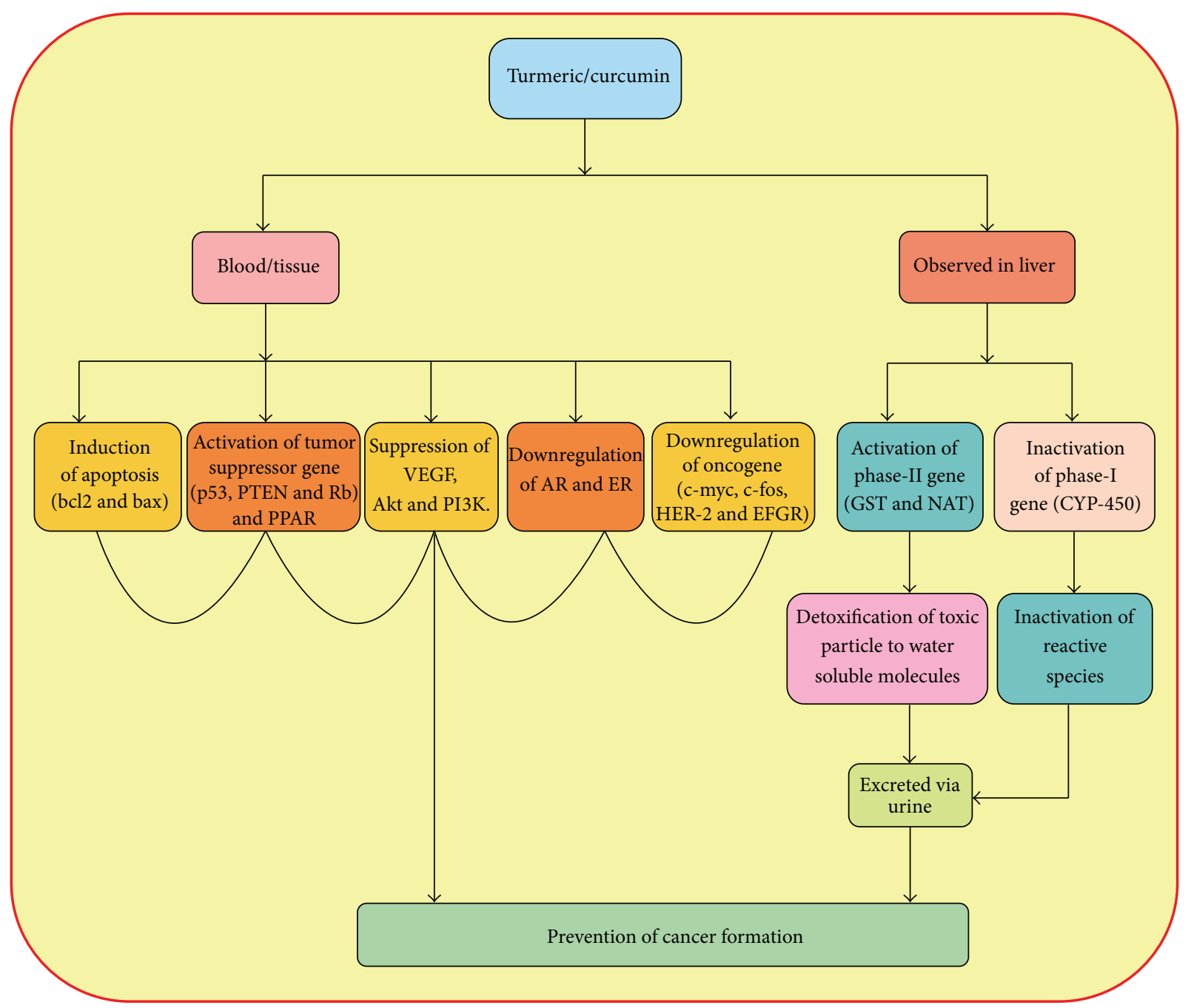

FIGURE 2: Turmeric/curcumin shows an important role in cancer prevention via induction of apoptosis, activation of tumour suppressor gene and phase II gene, and inactivation of oncogene, hormonal receptor gene, and angiogenesis and phase-I gene.

factor $2(\mathrm{NRF}-2)$ and $\mathrm{NF}-\kappa \mathrm{B}$ via an antioxidant response element [78].

\subsection{Androgen Degradation/Down Regulation by Curcumin.} The androgen receptor (AR) is a ligand activated steroid hormone receptor that plays a vital and significant role in developing the function of normal prostrate as well as in prostate cancer development and progression [79, 80]. Change in the function or overexpression of AR has been observed in cancer [81]. The treatment basis on allopath like hormone therapy was considered as a potential treatment, but its limitation/disadvantage as prostate cancer cells become progressive and may lead to metastasis [82]. The regulation of AR activities is a critical step in the control or suppression of tumor development and progression. An important study of curcumin on androgen dependent LNCaP prostate cancer cell line and an androgen independent PC-3 prostate cancer cell showed that AR protein level is downregulated [83]. Earlier studies had shown that curcumin downregulates the transactivation and expression of AR and AR-related cofactors [84]. The constituent has a potential therapeutic effect on prostate cancer cells through the downregulation of AR and AR-related cofactors AP-1, NF, and CBP [84]. Another study reported that curcumin acts as an inducer of apoptosis in both androgen-dependent and hormone refractory prostate cancer cells [85]. Curcumin blocks the activation of androgen and IL- 6 on prostate-specific antigen expression in human prostatic carcinoma cells [86].

\subsection{Effect of Curcumin on PI3 K/Akt Pathways. PI3 K/Akt} signalling pathway is important and critical in mediating cell survival, proliferation, migration, and angiogenesis. PI3 K catalyzes the production of the lipid secondary messenger phosphatidylinositol-3,4,5-triphosphate including the serine/threonine kinase Akt [87, 88]. Mutation and/or loss of PTEN function plays an important role in the activation of PI3 K and is associated with the growth and progression of various types of cancers [89, 90]. Activated PI3 K shows a role in the conversion of phosphatidylinositol 
into PtdIns(3,4)P2 (PIP2) and PtdIns(3,4,5)P3 (PIP3). Phosphatidylinositol dependent kinases $1 / 2$ (PDKs $1 / 2$ ) play a key role in the phosphorylation of Akt at residues Thr308 and Ser473 [91-93]. Activated Akt plays a role in promoting cell survival by suppressing apoptosis via subsequent modulation of a wide range of target molecules [94-97]. PTEN, a tumor suppressor gene, is a multifunctional phosphatase whose major substrate is phosphatidylinositol-3,4,5-trisphosphate (PIP3) [98]. Phosphatase activity of PTEN plays an important effect in dephosphorylation of PIP3. By this way PTEN negatively regulates the phosphoinositide-3-kinase (PI3 K)$\mathrm{PKB} /$ Akt pathway and prevents the tumor development or tumor suppression. The inhibition of the PI3 K/Akt and activation of PTEN pathway is a good strategy in the prevention of cancer. An important study showed that curcumin inhibits the phosphorylation of Akt, mTOR, and their downstream substrates, and this inhibitory effect acts downstream of phosphatidylinositol 3-kinase and phosphatidylinositoldependent kinase1 [99].

2.7. Effect of Curcumin on Cycloxygenase Enzyme. COX is an inducible enzyme in the conversion of arachidonic acid to prostaglandins (PGs). There are two types of cycloxygenase: COX1 plays a vital role in physiological functions and COX2 is upregulated or overexpressed in various types of cancers [100-102]. It was previously stated that curcumin inhibits the critical stage of tumor initiation and promotion stages $[103,104]$ and COX inhibition [105]. Curcumin also inhibits the COX2 expression on colon cancer cell lines [106]. Earlier studies reported that curcumin plays an important role in the downregulation of the expression of COX-2 and finally prevents or suppresses the cancer progression [107]. Moreover, curcumin plays a significant role in the cancer prevention via controlling the activities of various genes in the initiation, promotion, and progression stage of tumor development and progression (Figure 3).

2.8. NF- $\kappa B$ and Curcumin in Cancer Prevention. NF- $\kappa \mathrm{B}$ family of transcription factors shows an important role in immune, inflammatory response and also stimulates the development and progression of cancer. In this regard, an important study demonstrated that curcumin showed as an anticancer, antioxidant, and anti-inflammatory effect via the downregulation of the transcription factors NF- $\kappa \mathrm{B}, \mathrm{AP}-1$, and Egr-1 [108] and repression of the genes for cell adhesion molecules (chemokines, TNF, Cox-2, and MMP-9) [109, 110]. Another study showed that curcumin is a pharmacologically safe agent and has been involved in the suppression of NF- $\kappa \mathrm{B}$ activation and $\mathrm{NF}-\kappa \mathrm{B}$ gene products [111].

An important study in pancreatic cancer cells reported that curcumin showed a vital role in the suppression of NF- $\kappa \mathrm{B}$ activation by inhibiting $\mathrm{I} \kappa \mathrm{B}$ kinase, ultimately induces $\mathrm{I} \kappa \mathrm{B} \alpha$ phosphorylation, and inhibits the NF- $\kappa \mathrm{B}$ downstream gene expression [112].

Several findings showed that curcumin suppresses the expression of a variety of NF- $\kappa \mathrm{B}$ regulated gene products involved in cancer development and progression such as cyclin D1, VEGF, COX-2, c-myc, Bcl-2, ICAM-1, and MMP-9 $[110,113-115]$.

Numerous studies has shown that curcumin is a potent inhibitor of NF- $\kappa$ B activation [63, 109, 111, 116-119].

2.9. Effect of Curcumin on Oncogene. Alteration or mutation of protooncogene is key factors in the development and progression of various types of tumours. An activated oncogene has been noticed in various types of cancer [120-122]. Safe route of inactivation of an oncogene is a prime interest in the prevention of tumor. Several earlier investigations reported that curcumin shows a significant effect in cancer prevention via the inactivation of oncogene. Curcumin downregulated N-Myc [123] in various cancer types and decreased the expression of proto-oncogenes such as ras and fos in tumorous skin [124]. A report on the effect of curcumin in hepatocellular carcinoma revealed that curcumin blocked transactivation of the c-Met promoter through AP-1 [125]. Another finding on curcumin effect in the downregulation of oncogene showed that curcumin induced the antiproliferative, antimigratory and apoptotic effects via the downregulation of various genes, including c-Myc, N-Myc, cyclin D1, and antiapoptotic factors Bcl-2 and Bcl-xL [126]. Several other studies showed the effect of curcumin in the inhibition or downregulation of various oncogenes such as EGFR, HER-2, PI3 K/Akt, and MAPK pathway [127-131]. Curcumin is involved in the induction of apoptosis through downregulating the expression of c-myc, $\mathrm{Bcl}-2$, and mutant-type $\mathrm{p} 53$, and upregulating the expression of Fas [132].

2.10. Effect of Curcumin on Signal Transducer and Activator of Transcription 3 (STAT3). The Signal Transducer and Activator of Transcription 3 (STAT3) protein is one of the important members of the STAT family of transcription factors [133]. STA3 plays a role in the cancer development and progression and overexpression or high level of STAT3 has been observed in various types of cancers [134, 135]. Curcumin inhibits constitutive STAT3 phosphorylation [136]. Other results also show that the curcumin significantly suppressed Stat3 phosphorylation in bronchoepithelial cells and lung cancer derived cells, indicative of Stat 3 pathway suppression, and finally inhibits the proliferative capacity of bronchoepithelial cells and lung cancer cells [137].

\subsection{Effect of Curcumin in Peroxisome Proliferator-Activated} Receptors (PPARs). PPARs belong to the super family of nuclear receptors, containing three genes that give different subtypes such as PPAR- $\alpha$, PPAR- $\delta$, and PPAR- $\gamma$ [138]. Curcumin showed a role in the upregulation of PPAR- $\gamma$ [139] and interrupted with PDGF and EGF signaling, stimulated gene expression of PPAR $\gamma$, and thereby plays a role in the inhibition of cell proliferation of activated HSCs [140]. A study of curcumin effects on colon cancer cells confirmed that growth inhibition and stimulation of the transactivating activity of peroxisome proliferator-activated receptor c (PPAR-c), which appears to mediate the suppression of gene expression of 


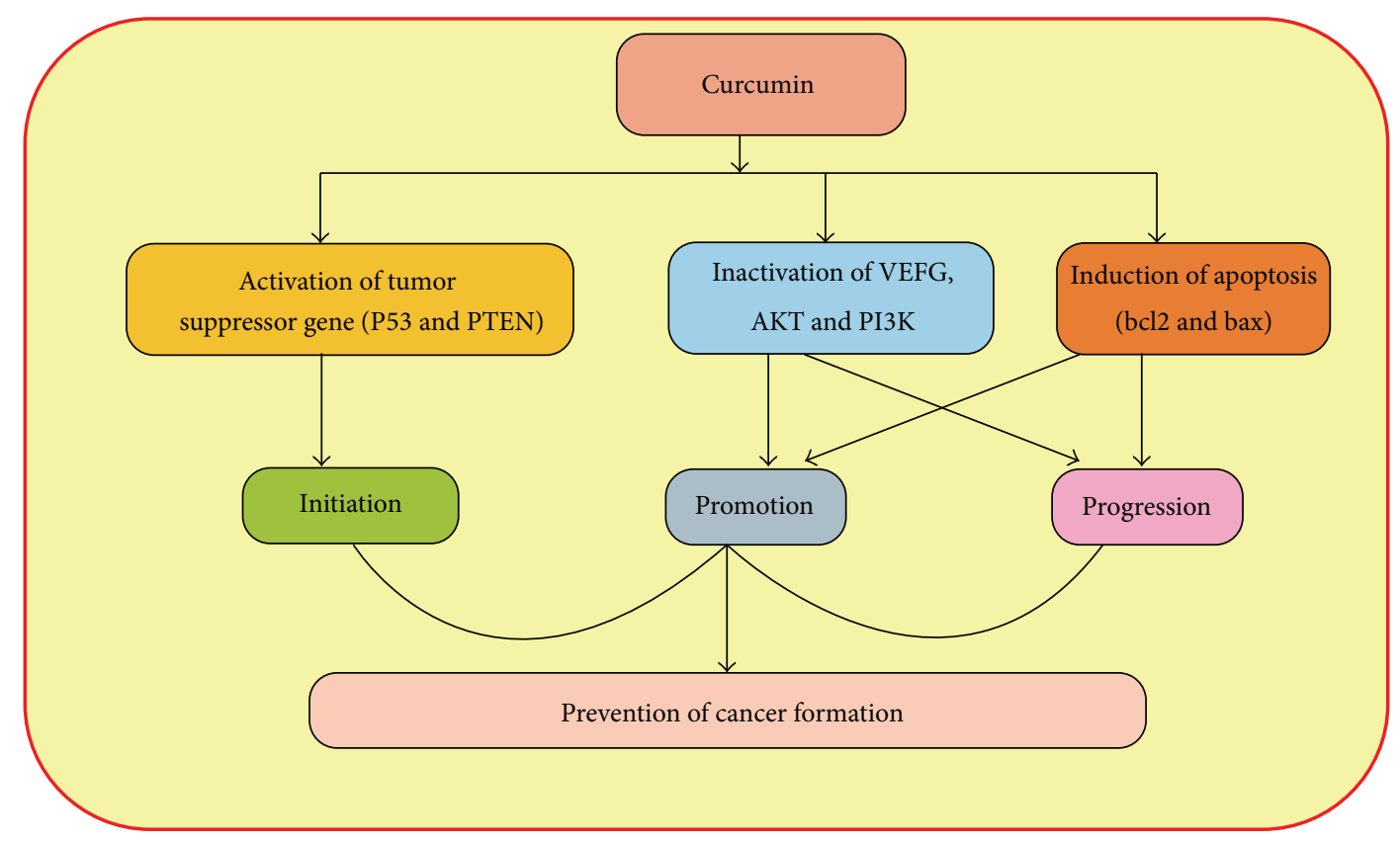

FIGURE 3: Curcumin shows an important role in the prevention of cancer through the inhibition of initiation, promotion, and progression steps via modulation of molecular cascades.

cyclin D1 and the epidermal growth factor receptor (EGFR) [141].

2.12. Effect of Curcumin on Matrix Metalloproteinases-9 (MMP-9). Matrix metalloproteinases (MMPs) have been considered as one of the important vital molecules assisting tumor cells during metastasis [142-145]. MMP9, member of the matrix metalloproteinases (MMPs), shows a major role in the breakdown of extracellular matrix in normal physiological processes, including embryonic development, reproduction, and tissue remodeling, as well as in disease processes such as tumor metastasis [146]. Altered expression of MMP-9 has been observed in various types of tumors. However, curcumin shows a vital role in the inhibition of MMP-9 activities and finally plays a role in the management of cancer. A study showed that curcumin inhibits TPAinduced MMP-9 expression and cell invasion through suppressing NF- $\kappa$ B and AP-1 activation [147].

Another study showed that curcumin significantly inhibited the MMP-9 enzymatic activity and protein expression that was induced by PMA [148]. An important study has shown in a human breast cancer xenograft model that administration of curcumin noticeably decreased metastasis to lung and suppressed the expression of NF- $\kappa \mathrm{B}, \mathrm{MMP}-9$, COX-2, VEGF, and intercellular adhesion molecule-1 [149]. Earlier results suggest that curcumin plays a role in regulating cell metastasis by inhibiting MMP-2 and MMP-9 in breast cancer cell line [150]. Curcumin showed inhibition of phorbol ester-induced upregulation of cyclooxygenase- 2 and matrix metalloproteinase-9 in MCF10A human breast epithelial cells study [151].

\section{Clinical Trials Based Study of Curcumin}

Several valuable clinical trials have been performed using turmeric and its constituents to check their efficacy and safety. Curcumin shows the chemopreventive effect in various types of tumor via modulation of biological processes. An important study based on twenty-five patients with several different premalignant or high-risk lesions suggested that oral curcumin may have chemopreventive effects on the progression of these lesions [152]. Another uncontrolled study based on advanced colorectal cancer refractory to standard treatments, glutathione $\mathrm{S}$ transferase, has shown a $59 \%$ reduction in the activity with the oral curcumin extract dose of $440 \mathrm{mg}$ daily and five patients maintained radiologically stable disease over the 2- to 4-month study period [153]. Another study in chronic smokers was performed to check the antimutagenic effects of turmeric and it was found that that turmeric significantly reduced the urinary excretion of mutagens in smokers with doses of 1.5 gms/day for 30 days, whereas in the control group (nonsmokers), there was no change in the urinary excretion of mutagens after 30 days [154]. An important study was performed in 39 subjects (thirteen with dental caries, twentyone with head and neck cancer, and five healthy volunteers) and saliva was collected in $50 \mathrm{~mL}$ tubes, before and after one hour when subjects chewed two curcumin chaplets. It was found that curcumin treatment led to a reduction in IKK $\beta$ kinase activity in the salivary cells of head and neck squamous cell carcinoma [155]. A study was performed to evaluate the safety and feasibility of combination therapy using curcumin with gemcitabine-based chemotherapy on twenty-one patients and showed 8 gms oral curcumin daily with gemcitabine-based chemotherapy was safe and feasible 
in patients with pancreatic cancer [156]. Another important study was performed on patients with colorectal cancer and patients were ingested curcumin capsules with a dose of (3.6 g, 1.8 and $4.5 \mathrm{~g}$ daily) for 7 days. This finding suggests that a daily dose of 3.6 grams curcumin is pharmacologically effective in the colorectum with negligible distribution of curcumin outside the gut [157].

\section{Toxicity of Curcumin}

Turmeric and its constituents play a vital role in the management of various diseases including cancer. Toxicity and lethal dose level of curcumin are important before using in health management. Several studies were performed to check the safe dose of curcumin in animal model studies. No significant toxicity was observed of turmeric and its constituent curcumin at various doses. An important study in which animals were fed curcumin with a dose of $1.8 \mathrm{gms} / \mathrm{kg}$ and $0.8 \mathrm{mg} / \mathrm{kg}$ in rat and monkey, respectively, for 90 days showed no adverse effects [158]. An important study in which animals were fed curcumin with a dose of $1.8 \mathrm{gms} / \mathrm{kg}$ and $0.8 \mathrm{mg} / \mathrm{kg}$ in rat and monkey, respectively, for 90 days showed no adverse effects [158]. Curcumin is remarkably well tolerated, but its bioavailability is poor. It does not show to be toxic to humans [159] even at high doses. Earlier studies concluded that combination therapy using $8 \mathrm{~g}$ oral curcumin daily with gemcitabine-based chemotherapy was safe and feasible in patients with pancreatic cancer [156] and other study concluded that oral curcumin is well tolerated and, despite its limited absorption, showed biological activity [160]. An important study based on advanced pancreatic cancer patients showed that 5 patients out of 17 patients receiving curcumin with dose 8 gms/day with gemcitabine showed intractable abdominal pain after a few days to 2 weeks of curcumin intake [161].

A study reported that hepatotoxicity was seen in mice fed with whole turmeric $(0.2 \%, 1 \%, 5 \%)$ or ethanolic turmeric extract (ETE; $0.05 \%, 0.25 \%$ ) for 14 days [162]. Earlier report based on curcumin has shown that curcumin doses ranging from 0.45 to $3.6 \mathrm{gms} /$ day for 1 to 4 months showed nausea and diarrhea and also caused an increase in serum alkaline phosphatase and lactate dehydrogenase contents [163].

\section{Role of Analogue/Derivatives of Curcumin}

Some drugs due to their hydrophobic nature show poor bioavailability and a very low quantity of drugs go to the target tissues and show less activity. Low bioavailability of curcumin, due to its low aqueous solubility, has been a major obstacle for its clinical development as a therapeutic drug [164].

However, increasing the absorption of drugs for better activity is the main research of interest in this vista. Analogues or derivatives of drugs show higher absorption and better activity without any adverse complications. Nanoparticle/encapsulation systems give better efficacy and bioavaibility of drugs and also provide the best option in the health management without any untoward effects. Several medicinal plants and their constituents play a significant role in disease management via modulation of various biological activities. But medicinal plants and their constituents show some limitation in the term of efficacy due to the low absorption capacity. Therefore, in clinical trials of oral administration of curcumin to human cancer patients, the systemic availability of curcumin was found to be negligible because of poor absorption of the compound [153, 157].

Clinical trials based studies showed that various types of derivatives such as FLLL 11 and FLLL 12, RL 90, RL91, and GO-YO30 play a significant role as therapeutic drugs.

Earlier investigators showed that GO-Y030, curcumin analogue, inhibited colorectal carcinoma cell growth in vitro and in a mouse model [165] and this analogue also inhibits STAT3 activity and cell growth in the breast and pancreatic carcinomas [166]. The inhibition of STAT3 via GO-Y030 also plays an important role in downregulation of the expression of STAT3-regulated genes in colorectal cancer stem cells, such as Cyclin D1 [167], surviving [168], Bcl-2, and BclXL $[167,169]$. An important study showed that GO-Y030 reduced the STAT3 downstream target gene expression and induced apoptosis in colon cancer stem cells [170].

Another important study reported that analogues such as GO-Y030 and GO-Y078 showed 7- to 12-fold more potent growth suppression of myeloma cells and showed 6- to 15-fold stronger inhibition of NF- $\kappa$ B, PI3 K/AKT, JAK/STAT3, and IRF4 pathways than curcumin [171]. In MDA-MB-231 cells GOYO30 has a reported IC50 of $1.2 \mu \mathrm{M}$ [172], significantly less than curcumin.

An important study has compared the inhibitory efficacy of analogues of curcumin such as GO-Y030, FLLL11, and FLLL-12 in colorectal cancer cell lines including HCT116, HT-29, and SW480 and found that GOY030, FLLL11, and FLLL-12 showed more potent inhibition of cell viability/proliferation in all HCT116, HT-29, and SW480 human colorectal carcinoma as compared to curcumin [166].

Earlier investigators reported that analogues such as FLLL11 and FLLL12 showed more potency than curcumin at inhibiting cell viability, cell migration, and colony formation in soft agar than curcumin, and theses analogues induced apoptosis in human breast and prostate cancer cells. FLLL11 and FLLL12 analogues of curcumin also synergize with doxorubicin to suppress the growth of MDA-MB-231 breast cancer cells [173]. Earlier investigators showed that D6 compound promotes apoptosis in melanoma cells via the mitochondrial intrinsic pathway [174]. The analogues such as 2,6-bis(pyridin-3-ylmethylene)-cyclohexanone (RL90) and 2,6-bis(pyridin-4-ylmethylene)-cyclohexanone (RL91) modulated the expression of cell signaling proteins, specifically, in SKBr3 cells, protein levels of Her-2, Akt, and NF $\kappa$ B were decreased whereas activity of stress kinases JNK1/2 and P38 MAPK were increased [175].

A recent study showed that RL66 decreased the phosphorylation of Akt on Ser-473 in a time-dependent manner. RL66 decreased Akt phosphorylation after $6 \mathrm{~h}$ in MDA-MB-231 cells, whereas the phosphorylation of Akt was only decreased after $36 \mathrm{~h}$ in MDA-MB-468 cells [176]. Other studies also reported that RL66 had superior cytotoxicity compared to other analogs of curcumin such as 3,5-bis(flurobenzylidene) 
piperidin-4-one (EF24) [177], 5-bis(4-hydroxy-3-methoxybenzylidnen)-N-methyl-4-piperidone [178] (PAC) and GOY030 [172] in MDA-MB-231 cells.

\section{Bioavailability of Curcumin}

Curcumin shows a vital role in health management through the modulation of various biological activities including regulation of molecular pathways. Therefore, in spite of its potential effects in health benefits of curcumin are limited due to its poor solubility, low absorption from the gut, rapid metabolism, and rapid systemic elimination [179]. Enhancement of absorption, solubility, and slowing down the rapid metabolism of curcumin are a main interest of research in medical sciences. In this vista, various studies based on animal model and clinical trials have proved that new formulation of curcumin based on nanoparticles, liposomes, and other new formulations shows a valuable role in health management due to high absorption, solubility, and slowing down the rapid metabolism compared to normal curcumin. However, new formulation of curcumin shows better therapeutic role in health management due to increased or enhanced bioavailability.

Curcumin revealed poor bioavailability has been well recognized by earlier finding [164] and a study reported that $10 \mathrm{mg} / \mathrm{kg}$ of curcumin given intravenously to rats yield a maximum serum level of $0.36 \pm 0.05 \mu \mathrm{g} / \mathrm{mL}$, whereas $500 \mathrm{mg} / \mathrm{kg}$ of curcumin administered orally only yielded a $0.06 \pm 0.01 \mu \mathrm{g} / \mathrm{mL}$ maximum serum level [180].

Furthermore, curcumin was given orally to rats at a dose of $2 \mathrm{~g} / \mathrm{kg}$, a maximum serum concentration of $1.35 \pm$ $0.23 \mu \mathrm{g} / \mathrm{mL}$ was observed at time 0.83 hours, while in humans the dose of $2 \mathrm{~g}$ of curcumin resulted in either undetectable or very low $(0.006 \pm 0.005 \mu \mathrm{g} / \mathrm{mL}$ at $1 \mathrm{~h})$ serum levels [181].

Therefore, new formulation based on adjuvants, nanoparticles, liposomes, micelles, and phospholipid complexes is currently evaluated/used to increase the bioavailability and biological activity of curcumin[182-186]. An important study formulated innovative preparation such as THERACURMIN and confirmed that its oral bioavailability is approximately 30-times higher than curcumin powder in both rats and humans and results also show that THERACURMIN enhanced gastrointestinal absorption as a result of colloidal dispersion [187]. Another study was performed to evaluate the safety and pharmacokinetics of newly developed nanoparticle curcumin with increased water solubility such as THERACURMIN and it was concluded that THERACURMIN can safely increase plasma curcumin levels in a dosedependent manner at least up to $210 \mathrm{mg}$ without saturating the absorption system [188]. A study also reported that curcumin loaded cellulose nanoparticles (cellulose-CUR) formulation showed the highest cellular uptake and caused maximum ultrastructural changes related to apoptosis in prostate cancer cells [169] and other study concluded that SFderived curcumin nanoparticles show higher efficacy against breast cancer cells and also have the potential to treat in vivo breast tumors [189].

A study was performed to evaluate the liposomal curcumin's potential against cancer models of mesenchymal
(OS) and epithelial origin and it was observed that 2Hydroxypropyl- $\gamma$-cyclodextrin/curcumin-liposome complex shows promising anticancer potential both in vitro and in vivo against KHOS OS cell line and MCF-7 breast cancer cell line [190].

A study based on in vivo pharmacokinetics showed that curcumin entrapped nanoparticles demonstrate at least 9fold increase in oral bioavailability as compared to curcumin administered with piperine as absorption enhancer [191] and study based on human colorectal cancer cell lines such as LoVo and Colo205 cells showed that in vitro treatment with liposomal curcumin induced a dose-dependent growth inhibition and apoptosis [192]. An important study showed that encapsulating the curcumin into the hydrogel nanoparticles yielded a homogenous curcumin dispersion in aqueous solution as compared to the free form of curcumin [193] and earlier finding observed that after oral administration of CUR-PLGA-NPs, the relative bioavailability was 5.6-fold increased and also showed longer half-life compared with that of native curcumin. Increased oral bioavailability of CUR may be linked with improved water solubility, higher release rate in the intestinal juice, enhanced absorption by improved permeability, inhibition of P-glycoprotein- (P-gp-) mediated efflux, and increased residence time in the intestinal cavity [194]. An important study has discussed in detail regarding the most recent development in bioavailability, absorption, and metabolism of curcumin in detail [195].

\section{Conclusions}

Cancer is a deadly disease for both men and women and also a major health problem worldwide. The present mode of treatment based on chemotherapy and radiotherapy is very expensive and also exhibits serious side effects in human beings. Keeping in view the significance of herbs, this review is written to show the role of curcumin in the prevention of various types of cancer through the activation or inactivation of various genetic pathways. These reported features combined with the absence of side effects and being inexpensive as well as easy to access, turmeric and its constituent curcumin may be proved very effective therapeutics in the management of cancers.

\section{Conflict of Interests}

The authors have no conflict of interests to disclose.

\section{References}

[1] A. Rahmani, M. Alzohairy, A. Y. Babiker, M. A. Rizvi, and G. H. Elkarimahmad, "Clinicopathological significance of PTEN and bcl 2 expressions in oral squamous cell carcinoma," International Journal of Clinical and Experimental Pathology, vol. 5, no. 9, pp. 965-971, 2012.

[2] A. Rahmani, M. Alzohairy, H. Khadri, A. K. Mandal, and M. A. Rizvi, "Expressional evaluation of vascular endothelial growth factor (VEGF) protein in urinary bladder carcinoma patients exposed to cigarette smoke," International Journal of Clinical and Experimental Pathology, vol. 5, no. 3, pp. 195-202, 2012. 
[3] J. Teng, Z.-Y. Wang, D. F. Jarrard, and D. E. Bjorling, "Roles of estrogen receptor $\alpha$ and $\beta$ in modulating urothelial cell proliferation," Endocrine-Related Cancer, vol. 15, no. 1, pp. 351364, 2008.

[4] Dar-ul-Iman Healing, "Food of the Prophet (Sallallaho Alayhi Wasallam)," 2000, http://chishti.org/foods_of_the_prophet.htm.

[5] M. I. Al-Bukhari, Sahi Al-Bukhari, The Collection of Authentic Sayings of Prophet Mohammad (peace be upon him), Division 71 on Medicine, Hilal Yayinlari, Ankara, Turkey, 2nd edition, 1976.

[6] A. H. Rahmani, S. M. Aly, H. Ali, A. Y. Babiker, S. Srikar, and A. A. Khan, "Therapeutic effects of date fruits (Phoenix dactylifera) in the prevention of diseases via modulation of antiinflammatory, antioxidant and anti-tumour activity," International Journal of Clinical and Experimental Medicine, vol. 7, pp. 483-491, 2014.

[7] A. H. Rahmani, A. S. Albutti, and S. M. Aly, "Therapeutics role of olive fruits/oil in the prevention of diseases via modulation of anti-oxidant, anti-tumour and genetic activity," International Journal of Clinical and Experimental Medicine, vol. 7, pp. 799808, 2014.

[8] A. H. Rahmani, M. A. Alzohairy, M. A. Khan, and S. M. Aly, "Therapeutic implications of black seed and its constituent thymoquinone in the prevention of cancer through inactivation and activation of molecular pathways," Evidence-Based Complementary and Alternative Medicine, vol. 2014, Article ID 724658, 13 pages, 2014.

[9] I. Chattopadhyay, K. Biswas, U. Bandyopadhyay, and R. K. Banerjee, "Turmeric and curcuminBiological actions and medicinal applications," Current Science, vol. 87, pp. 44-50, 2004.

[10] J. Milobedeska, V. Kostanecki, and V. Lampe, "Structure of curcumin," Berichte der Deutschen Chemischen Gesellschaft, vol. 43, pp. 2163-2170, 1910.

[11] V. Lampe and J. Milobedeska, "Studien über curcumin," Berichte der Deutschen Chemischen Gesellschaft, vol. 46, pp. 2235-2240, 1913.

[12] M. Sharma, R. Manoharlal, N. Puri, and R. Prasad, "Antifungal curcumin induces reactive oxygen species and triggers an early apoptosis but prevents hyphae development by targeting the global repressor TUP1 in Candida albicans," Bioscience Reports, vol. 30, no. 6, pp. 391-404, 2010.

[13] O. A. K. Khalil, O. M. M. de Faria Oliveira, J. C. R. Vellosa et al., "Curcumin antifungal and antioxidant activities are increased in the presence of ascorbic acid," Food Chemistry, vol. 133, no. 3, pp. 1001-1005, 2012.

[14] S. Prasad, S. C. Gupta, A. K. Tyagi, and B. B. Aggarwal, "Curcumin, a component of golden spice: from bedside to bench and back," Biotechnology Advances, 2014.

[15] M. Kanai, "Therapeutic applications of curcumin for patients with pancreatic cancer," World Journal of Gastroenterology, vol. 20, pp. 9384-9391, 2014.

[16] A. Rahmani, M. Alzohairy, A. K. Mandal, and M. A. Rizvi, "Expressional evaluation of androgen receptor in transitional cell carcinoma of urinary bladder patients," British Journal of Medicine and Medical Research, vol. 1, pp. 233-238, 2011.

[17] A. Y. Babiker, A. H. Rahmani, M. S. Abdalaziz et al., "Expressional analysis of p16 and cytokeratin19 protein in the genesis of oral squamous cell carcinoma patients," International Journal of Clinical and Experimental Medicine, vol. 7, pp. 1524-1530, 2014.

[18] S.-S. Han, S.-T. Chung, D. A. Robertson, D. Ranjan, and S. Bondada, "Curcumin causes the growth arrest and apoptosis of
B cell lymphoma by downregulation of egr-1, C-myc, Bcl-X(1), NF- $\kappa$ B, and p53," Clinical Immunology, vol. 93, no. 2, pp. 152-161, 1999.

[19] M.-J. Park, E.-H. Kim, I.-C. Park et al., "Curcumin inhibits cell cycle progression of immortalized human umbilical vein endothelial (ECV304) cells by up-regulating cyclin-dependent kinase inhibitor, p21WAF1/CIP1, p27KIP1 and p53," International Journal of Oncology, vol. 21, no. 2, pp. 379-383, 2002.

[20] G. Sa and T. Das, "Anti cancer effects of curcumin: cycle of life and death," Cell Division, vol. 3, article 14, 2008.

[21] S. Shankar and R. K. Srivastava, "Involvement of Bcl-2 family members, phosphatidylinositol 3/-kinase/AKT and mitochondrial p53 in curcumin (diferulolylmethane)- induced apoptosis in prostate cancer," International Journal of Oncology, vol. 30, no. 4, pp. 905-918, 2007.

[22] S. Ali, A. Ahmad, A. Aboukameel et al., "Increased Ras GTPase activity is regulated by miRNAs that can be attenuated by CDF treatment in pancreatic cancer cells," Cancer Letters, vol. 319, no. 2, pp. 173-181, 2012.

[23] S. Ali, A. Ahmad, S. Banerjee et al., "Gemcitabine sensitivity can be induced in pancreatic cancer cells through modulation of miR-200 and miR-21 expression by curcumin or its analogue CDF," Cancer Research, vol. 70, no. 9, pp. 3606-3617, 2010.

[24] B. Bao, S. Ali, S. Banerjee et al., "Curcumin analogue CDF inhibits pancreatic tumor growth by switching on suppressor microRNAs and attenuating EZH2 expression," Cancer Research, vol. 72, no. 1, pp. 335-345, 2012.

[25] B. Bao, S. Ali, D. Kong et al., "Anti-tumor activity of a novel compound-CDF is mediated by regulating miR-21, miR-200, and pten in pancreatic cancer," PLOS ONE, vol. 6, no. 3, Article ID e17850, 2011.

[26] R. A. Weinberg, "The retinoblastoma protein and cell cycle control," Cell, vol. 81, pp. 323-330, 1995.

[27] C. Broceño, S. Wilkie, and S. Mittnacht, "RB activation defect in tumor cell lines," Proceedings of the National Academy of Sciences of the United States of America, vol. 99, no. 22, pp. 14200-14205, 2002.

[28] J. S. Foster, D. C. Henley, A. Bukovsky, P. Seth, and J. Wimalasena, "Multifaceted regulation of cell cycle progression by estrogen: regulation of Cdk inhibitors and Cdc25A independent of cyclin D1-Cdk4 function," Molecular and Cellular Biology, vol. 21, no. 3, pp. 794-810, 2001.

[29] R. L. Sutherland and E. A. Musgrove, "Cyclins and breast cancer," Journal of Mammary Gland Biology and Neoplasia, vol. 9, no. 1, pp. 95-104, 2004.

[30] R. K. Srivastava, Q. Chen, I. Siddiqui, K. Sarva, and S. Shankar, "Linkage of curcumin-induced cell cycle arrest and apoptosis by cyclin-dependent kinase inhibitor p21/WAF1/CIP1," Cell Cycle, vol. 6, no. 23, pp. 2953-2961, 2007.

[31] A. Mukhopadhyay, S. Banerjee, L. J. Stafford, C. Xia, M. Liu, and B. B. Aggarwal, "Curcumin-induced suppression of cell proliferation correlates with down-regulation of cyclin D1 expression and CDK4-mediated retinoblastoma protein phosphorylation," Oncogene, vol. 21, no. 57, pp. 8852-8861, 2002.

[32] K. Hollowood and J. C. Macartney, "Reduced apoptotic cell death in follicular lymphoma," The Journal of Pathology, vol. 163, no. 4, pp. 337-342, 1991.

[33] L. Sachs and J. Lotem, "Control of programmed cell death in normal and leukemic cells: new implications for therapy," Blood, vol. 82, no. 1, pp. 15-21, 1993. 
[34] E. Tourkina, P. Gooz, J. C. Oates, A. Ludwicka-Bradley, R. M. Silver, and S. Hoffman, "Curcumin-induced apoptosis in scleroderma lung fibroblasts: Role of protein kinase Ce," The American Journal of Respiratory Cell and Molecular Biology, vol. 31, no. 1, pp. 28-35, 2004.

[35] J. Yu, X. Zhou, X. He, M. Dai, and Q. Zhang, "Curcumin induces apoptosis involving Bax/Bcl-2 in human hepatoma SMMC-7721 cells," Asian Pacific Journal of Cancer Prevention, vol. 12, no. 8, pp. 1925-1929, 2011.

[36] C. Ramachandran and W. You, "Differential sensitivity of human mammary epithelial and breast carcinoma cell lines to curcumin," Breast Cancer Research and Treatment, vol. 54, no. 3, pp. 269-278, 1999.

[37] Z. M. Shao, M. I. Dawson, X. S. Li et al., "p53 independent G0/G1 arrest and apoptosis induced by a novel retinoid in human breast cancer cells," Oncogene, vol. 11, pp. 493-504, 1995.

[38] T. Choudhuri, S. Pal, M. L. Agwarwal, T. Das, and G. Sa, "Curcumin induces apoptosis in human breast cancer cells through p53-dependent Bax induction," FEBS Letters, vol. 512, no. 1-3, pp. 334-340, 2002.

[39] J. H. Bae, J.-W. Park, and T. K. Kwon, "Ruthenium red, inhibitor of mitochondrial $\mathrm{Ca}^{2+}$ uniporter, inhibits curcumin-induced apoptosis via the prevention of intracellular $\mathrm{Ca}^{2+}$ depletion and cytochrome c release," Biochemical and Biophysical Research Communications, vol. 303, no. 4, pp. 1073-1079, 2003.

[40] S. Mukherjee, U. Ghosh, N. P. Bhattacharyya, R. K. Bhattacharya, S. Dey, and M. Roy, "Curcumin-induced apoptosis in human leukemia cell HL-60 is associated with inhibition of telomerase activity," Molecular and Cellular Biochemistry, vol. 297, no. 1-2, pp. 31-39, 2007.

[41] A. R. Hussain, M. Al-Rasheed, P. S. Manogaran et al., "Curcumin induces apoptosis via inhibition of $\mathrm{PI} 3^{\prime}$-kinase/AKT pathway in acute T cell leukemias," Apoptosis, vol. 11, no. 2, pp. 245-254, 2006.

[42] M. Tomita, H. Kawakami, J. N. Uchihara et al., "Curcumin (diferuloylmethane) inhibits constitutive active NF-kappaB, leading to suppression of cell growth of human T-cell leukemia virus type I-infected T-cell lines and primary adult T-cell leukemia cells," International Journal of Cancer, vol. 118, pp. 765$772,2006$.

[43] H.-W. Chen and H.-C. Huang, "Effect of curcumin on cell cycle progression and apoptosis in vascular smooth muscle cells," British Journal of Pharmacology, vol. 124, no. 6, pp. 1029-1040, 1998.

[44] B. Agarwal, P. Swaroop, P. Protiva, S. V. Raj, H. Shirin, and P. R. Holt, "Cox-2 is needed but not sufficient for apoptosis induced by Cox-2 selective inhibitors in colon cancer cells," Apoptosis, vol. 8, no. 6, pp. 649-654, 2003.

[45] M. A. Azuine and S. V. Bhide, "Chemopreventive effect of turmeric against stomach and skin tumors induced by chemical carcinogens in Swiss mice," Nutrition and Cancer, vol. 17, no. 1, pp. 77-83, 1992.

[46] C. Ramachandran, H. B. Fonseca, P. Jhabvala, E. A. Escalon, and S. J. Melnick, "Curcumin inhibits telomerase activity through human telomerase reverse transcritpase in MCF-7 breast cancer cell line," Cancer Letters, vol. 184, no. 1, pp. 1-6, 2002.

[47] T. Dorai, Y.-C. Cao, B. Dorai, R. Buttyan, and A. E. Katz, "Therapeutic potential of curcumin in human prostate cancer. III. Curcumin inhibits proliferation, induces apoptosis, and inhibits angiogenesis of LNCaP prostate cancer cells in vivo," Prostate, vol. 47, no. 4, pp. 293-303, 2001.
[48] L. Moragoda, R. Jaszewski, and A. P. N. Majumdar, "Curcumin induced modulation of cell cycle and apoptosis in gastric and colon cancer cells," Anticancer Research, vol. 21, no. 2, pp. 873878, 2001.

[49] R. Hanif, L. Qiao, S. J. Shiff, and B. Rigas, "Curcumin, a natural plant phenolic food additive, inhibits cell proliferation and induces cell cycle changes in colon adenocarcinoma cell lines by a prostaglandin-independent pathway," Journal of Laboratory and Clinical Medicine, vol. 130, no. 6, pp. 576-584, 1997.

[50] M. J. van Erk, E. Teuling, Y. C. M. Staal et al., "Time- and dosedependent effects of curcumin on gene expression in human colon cancer cells," Journal of Carcinogenesis, vol. 3, article 8, 2004.

[51] P. Sindhwani, J. A. Hampton, M. Baig, R. Keck, and S. Selman, "Curcumin: a food spice with cytotoxic activity against urinary bladder cancer," Journal of the American College of Surgeons, vol. 191, pp. 94-95, 2000.

[52] A. M. Kamat, G. Sethi, and B. B. Aggarwal, "Curcumin potentiates the apoptotic effects of chemotherapeutic agents and cytokines through down-regulation of nuclear factor- $\kappa \mathrm{B}$ and nuclear factor- $\kappa \mathrm{B}$-regulated gene products in IFN- $\alpha$-sensitive and IFN- $\alpha$-resistant human bladder cancer cells," Molecular Cancer Therapeutics, vol. 6, no. 3, pp. 1022-1030, 2007.

[53] P. Sindhwani, J. A. Hampton, M. M. Baig, R. Keck, and S. H. Selman, "Curcumin prevents intravesical tumor implantation of the MBT-2 tumor cell line in C3H mice," Journal of Urology, vol. 166, no. 4, pp. 1498-1501, 2001.

[54] C. Park, G. Y. Kim, G. D. Kim, B. T. Choi, Y.-M. Park, and Y. H. Choi, "Induction of G2/M arrest and inhibition of cyclooxygenase-2 activity by curcumin in human bladder cancer T24 cells," Oncology Reports, vol. 15, no. 5, pp. 1225-1231, 2006.

[55] S. D. Catz and J. L. Johnson, "Transcriptional regulation of bcl2 by nuclear factor $\kappa \mathrm{B}$ and its significance in prostate cancer," Oncogene, vol. 20, no. 50, pp. 7342-7351, 2001.

[56] J. L. Herrmann, F. Briones Jr., S. Brisbay, C. J. Logothetis, and T. J. McDonnell, "Prostate carcinoma cell death resulting from inhibition of proteasome activity is independent of functional Bcl-2 and p53," Oncogene, vol. 17, no. 22, pp. 2889-2899, 1998.

[57] S. Liekens, E. De Clercq, and J. Neyts, "Angiogenesis: regulators and clinical applications," Biochemical Pharmacology, vol. 61, no. 3, pp. 253-270, 2001.

[58] J. Folkman, "Tumor angiogenesis theraperutic implications," The New England Journal of Medicine, vol. 285, pp. 1182-1186, 1971.

[59] S. Shishodia, M. M. Chaturvedi, and B. B. Aggarwal, "Role of curcumin in cancer therapy," Current Problems in Cancer, vol. 31, no. 4, pp. 243-305, 2007.

[60] H.-P. Gerber, V. Dixit, and N. Ferrara, "Vascular endothelial growth factor induces expression of the antiapoptotic proteins Bcl-2 and A1 in vascular endothelial cells," The Journal of Biological Chemistry, vol. 273, no. 21, pp. 13313-13316, 1998.

[61] A. B. Kunnumakkara, S. Guha, S. Krishnan, P. Diagaradjane, J. Gelovani, and B. B. Aggarwal, "Curcumin potentiates antitumor activity of gemcitabine in an orthotopic model of pancreatic cancer through suppression of proliferation, angiogenesis, and inhibition of nuclear factor- $\kappa \mathrm{B}$-regulated gene products," Cancer Research, vol. 67, no. 8, pp. 3853-3861, 2007.

[62] A. K. Singh, G. S. Sidhu, T. Deepa, and R. K. Maheshwari, "Curcumin inhibits the proliferation and cell cycle progression of human umbilical vein endothelial cell," Cancer Letters, vol. 107, no. 1, pp. 109-115, 1996. 
[63] R. Mohan, J. Sivak, P. Ashton et al., "Curcuminoids inhibit the angiogenic response stimulated by fibroblast growth factor- 2 , including expression of matrix metalloproteinase gelatinase B," The Journal of Biological Chemistry, vol. 275, no. 14, pp. 1040510412, 2000.

[64] C. C. Chua, R. C. Hamdy, and B. H. L. Chua, "Mechanism of transforming growth factor- $\beta 1$-induced expression of vascular endothelial growth factor in murine osteoblastic MC3T3-E1 cells," Biochimica et Biophysica Acta-Molecular Cell Research, vol. 1497, no. 1, pp. 69-76, 2000.

[65] G. Chadalapaka, I. Jutooru, S. Chintharlapalli et al., "Curcumin decreases specificity protein expression in bladder cancer cells," Cancer Research, vol. 68, no. 13, pp. 5345-5354, 2008.

[66] S. Singh and B. B. Aggarwal, "Activation of transcriptionfactor $\mathrm{NF} \kappa \mathrm{B}$ is suppressed by curcumin (diferuloylmethane)," Journal of Biological Chemistry, vol. 270, pp. 24995-25000, 1995.

[67] Z. J. Sun, G. Chen, W. Zhang et al., "Curcumin dually inhibits both mammalian target of rapamycin and nuclear factor- $\kappa \mathrm{B}$ pathways througha crossed phosphatidylinositol 3kinase/Akt/I $\kappa \mathrm{B}$ kinase complex signaling axis in adenoid cystic carcinoma," Molecular Pharmacology, vol. 79, pp. 106-118, 2011.

[68] R. Thapliyal and G. B. Maru, "Inhibition of cytochrome P450 isozymes by curcumins in vitro and in vivo," Food and Chemical Toxicology, vol. 39, no. 6, pp. 541-547, 2001.

[69] P. F. Firozi, V. S. Aboobaker, and R. K. Bhattacharya, "Action of curcumin on the cytochrome P450-system catalyzing the activation of aflatoxin B1," Chemico-Biological Interactions, vol. 100, no. 1, pp. 41-51, 1996.

[70] H. P. Ciolino, P. J. Daschner, T. T. Y. Wang, and G. C. Yeh, "Effect of curcumin on the aryl hydrocarbon receptor and cytochrome P450 1A1 in MCF-7 human breast carcinoma cells," Biochemical Pharmacology, vol. 56, no. 2, pp. 197-206, 1998.

[71] S. V. Singh, X. Hu, S. K. Srivastava et al., "Mechanism of inhibition of benzo[a]pyrene-induced forestomach cancer in mice by dietary curcumin," Carcinogenesis, vol. 19, no. 8, pp. 1357-1360, 1998.

[72] R. Thapliyal, S. S. Deshpande, and G. B. Maru, "Mechanism(s) of turmeric-mediated protective effects against benzo(a)pyrenederived DNA adducts," Cancer Letters, vol. 175, no. 1, pp. 79-88, 2002.

[73] R. A. Sharma, C. R. Ireson, R. D. Verschoyle et al., "Effects of dietary curcumin on glutathione S-transferase and malondialdehyde-DNA adducts in rat liver and colon mucosa: relationship with drug levels," Clinical Cancer Research, vol. 7, no. 5, pp. 1452-1458, 2001.

[74] T. Nishinaka, Y. Ichijo, M. Ito et al., "Curcumin activates human glutathione S-transferase P1 expression through antioxidant response element," Toxicology Letters, vol. 170, no. 3, pp. 238247, 2007.

[75] J. T. Piper, S. S. Singhal, M. S. Salameh, R. T. Torman, Y. C. Awasthi, and S. Awasthi, "Mechanisms of anticarcinogenic properties of curcumin: the effect of curcumin on glutathione linked detoxification enzymes in rat liver," The International Journal of Biochemistry \& Cell Biology, vol. 30, no. 4, pp. 445456, 1998.

[76] S. P. Valentine, M. J. Le Nedelec, A. R. Menzies, M. J. Scandlyn, M. G. Goodin, and R. J. Rosengren, "Curcumin modulates drug metabolizing enzymes in the female Swiss Webster mouse," Life Sciences, vol. 78, no. 20, pp. 2391-2398, 2006.

[77] R. Garg, S. Gupta, and G. B. Maru, "Dietary curcumin modulates transcriptional regulators of phase I and phase II enzymes in benzo[a]pyrene-treated mice: mechanism of its anti-initiating action," Carcinogenesis, vol. 29, no. 5, pp. 10221032, 2008.

[78] J. Park and C. N. Conteas, "Anti-carcinogenic properties of curcumin on colorectal cancer," World Journal of Gastrointestinal Oncology, vol. 2, pp. 169-176, 2010.

[79] W. Gao, C. E. Bohl, and J. T. Dalton, "Chemistry and structural biology of androgen receptor," Chemical Reviews, vol. 105, no. 9, pp. 3352-3370, 2005.

[80] C. A. Heinlein and C. Chang, "Androgen receptor in prostate cancer," Endocrine Reviews, vol. 25, no. 2, pp. 276-308, 2004.

[81] A. H. Rahmani, M. Alzohairy, A. Y. Y. Babiker, A. A. Khan, S. M. Aly, and M. A. Rizvi, "Implication of androgen receptor in urinary bladder cancer: a critical mini review," International Journal of Molecular Epidemiology and Genetics, vol. 4, pp. 150$155,2013$.

[82] B. J. Feldman and D. Feldman, "The development of androgenindependent prostate cancer," Nature Reviews Cancer, vol. 1, no. 1 , pp. 34-45, 2001.

[83] H. Guo, Y.-M. Xu, Z.-Q. Ye, J.-H. Yu, and X.-Y. Hu, "Curcumin induces cell cycle arrest and apoptosis of prostate cancer cells by regulating the expression of $\mathrm{I} \kappa \mathrm{B} \alpha$, c-Jun and androgen receptor," Pharmazie, vol. 68, no. 6, pp. 431-434, 2013.

[84] K. Nakamura, Y. Yasunaga, T. Segawa et al., "Curcumin downregulates AR gene expression and activation in prostate cancer cell lines," International Journal of Oncology, vol. 21, no. 4, pp. 825-830, 2002

[85] T. Dorai, N. Gehani, and A. Katz, "Therapeutic potential of curcumin in human prostate cancer-I. Curcumin induces apoptosis in both androgen-dependent and androgen-independent prostate cancer cells," Prostate Cancer and Prostatic Diseases, vol. 3, no. 2, pp. 84-93, 2000.

[86] K.-H. Tsui, T.-H. Feng, C.-M. Lin, P.-L. Chang, and H.-H. Juang, "Curcumin blocks the activation of androgen and interlukin6 on prostate-specific antigen expression in human prostatic carcinoma cells," Journal of Andrology, vol. 29, no. 6, pp. 661$668,2008$.

[87] B. Li, W. Xu, C. Luo, D. Gozal, and R. Liu, "VEGF-induced activation of the PI3-K/Akt pathway reduces mutant SOD1mediated motor neuron cell death," Molecular Brain Research, vol. 111, no. 1-2, pp. 155-164, 2003.

[88] E. R. Isenovic, Y. Meng, A. Divald, N. Milivojevic, and J. R. Sowers, "Role of phosphatidylinositol 3-kinase/Akt pathway in angiotensin II and insulin-like growth factor-1 modulation of nitric oxide synthase in vascular smooth muscle cells," Endocrine, vol. 19, no. 3, pp. 287-291, 2002.

[89] A. J. Philp, I. G. Campbell, C. Leet et al., "The phosphatidylinositol 3/-kinase p $85 \alpha$ gene is an oncogene in human ovarian and colon tumors," Cancer Research, vol. 61, no. 20, pp. 7426-7429, 2001.

[90] H. K. Roy, B. F. Olusola, D. L. Clemens et al., "AKT protooncogene overexpression is an early event during sporadic colon carcinogenesis," Carcinogenesis, vol. 23, no. 1, pp. 201-205, 2002.

[91] D. D. Sarbassov, D. A. Guertin, S. M. Ali, and D. M. Sabatini, "Phosphorylation and regulation of Akt/PKB by the rictormTOR complex," Science, vol. 307, no. 5712, pp. 1098-1101, 2005.

[92] C. Belham, S. Wu, and J. Avruch, "Intracellular signalling: PDK1-a kinase atthe hub of things," Current Biology, vol. 9, pp. 93-96, 1999. 
[93] S. I. Yu, G. Shen, O. K. Tin, J.-H. Kim, and A.-N. T. Kong, "Curcumin inhibits Akt/mammalian target of rapamycin signaling through protein phosphatase-dependent mechanism," Molecular Cancer Therapeutics, vol. 7, no. 9, pp. 2609-2620, 2008.

[94] M. H. Cardone, N. Roy, H. R. Stennicke et al., "Regulation of cell death protease caspase- 9 by phosphorylation," Science, vol. 282, no. 5392, pp. 1318-1321, 1998.

[95] M. Pap and G. M. Cooper, "Role of glycogen synthase kinase-3 in the phosphatidylinositol 3- kinase/Akt cell survival pathway," The Journal of Biological Chemistry, vol. 273, no. 32, pp. 1992919932, 1998.

[96] C. Rommel, B. A. Clarke, S. Zimmermann et al., "Differentiation stage-specific inhibition of the Raf-MEK-ERK pathway by Akt," Science, vol. 286, no. 5445, pp. 1738-1741, 1999.

[97] S. Pugazhenthit, A. Nesterova, C. Sable et al., "Akt/protein kinase $\mathrm{B}$ up-regulates $\mathrm{Bcl}-2$ expression through cAMP-response element-binding protein," The Journal of Biological Chemistry, vol. 275, no. 15, pp. 10761-10766, 2000.

[98] T. Maehama and J. E. Dixon, "The tumor suppressor, PTEN/MMAC1, dephosphorylates the lipid second messenger, phosphatidylinositol 3,4,5-trisphosphate," The Journal of Biological Chemistry, vol. 273, no. 22, pp. 13375-13378, 1998.

[99] S. Yu, G. Shen, T. O. Khor, J.-H. Kim, and A.-N. T. Kong, "Curcumin inhibits Akt/mammalian target of rapamycin signaling through protein phosphatase-dependent mechanism," Molecular Cancer Therapeutics, vol. 7, no. 9, pp. 2609-2620, 2008.

[100] R. A. Gupta and R. N. DuBois, "Colorectal cancer and the cyclooxygenase pathway," Nature Reviews Cancer, vol. 1, pp. 1121, 2001.

[101] A. Koki, N. K. Khan, B. M. Woerner et al., "Cyclooxygenase2 in human pathological disease," Advances in Experimental Medicine and Biology, vol. 507, pp. 177-184, 2002.

[102] A. G. Asting, H. Carén, M. Andersson, C. Lönnroth, K. Lagerstedt, and K. Lundholm, "COX-2 gene expression in colon cancer tissue related to regulating factors and promoter methylation status," BMC Cancer, vol. 11, article 238, 2011.

[103] M.-T. Huang, W. Ma, Y.-P. Lu et al., "Effects of curcumin, demethoxycurcumin, bisdemethoxycurcumin and tetrahydrocurcumin on 12-O-tetradecanoylphorbol-13acetate-induced tumor promotion," Carcinogenesis, vol. 16, no. 10, pp. 2493-2497, 1995.

[104] C. V. Rao, A. Rivenson, B. Simi, and B. S. Reddy, "Chemoprevention of colon carcinogenesis by dietary curcumin, a naturally occurring plant phenolic compound," Cancer Research, vol. 55, no. 2, pp. 259-266, 1995.

[105] M.-T. Huang, T. Lysz, T. Ferraro, T. F. Abidi, J. D. Laskin, and A. H. Conney, "Inhibitory effects of curcumin on in vitro lipoxygenase and cyclooxygenase activities in mouse epidermis," Cancer Research, vol. 51, no. 3, pp. 813-819, 1991.

[106] A. Goel, C. R. Boland, and D. P. Chauhan, "Specific inhibition of cyclooxygenase-2 (COX-2) expression by dietary curcumin in HT-29 human colon cancer cells," Cancer Letters, vol. 172, no. 2, pp. 111-118, 2001.

[107] B. B. Aggarwal, A. Kumar, and A. C. Bharti, "Anticancer potential of curcumin: preclinical and clinical studies," Anticancer Research, vol. 23, no. 1A, pp. 363-398, 2003.

[108] S.-S. Han, Y.-S. Keum, H.-J. Seo, and Y.-J. Surh, "Curcumin suppresses activation of NF- $\kappa$ B and AP-1 induced by phorbol ester in cultured human promyelocytic leukemia cells," Journal of Biochemistry and Molecular Biology, vol. 35, no. 3, pp. 337342, 2002.

[109] C. Jobin, C. A. Bradham, M. P. Russo et al., "Curcumin blocks cytokine-mediated NF- $\kappa$ B activation and proinflammatory gene expression by inhibiting inhibitory factor I- $\kappa \mathrm{B}$ kinase activity," The Journal of Immunology, vol. 163, no. 6, pp. 34743483, 1999.

[110] S. Singh and B. B. Aggarwal, "Activation of transcription factor $\mathrm{NF}-\kappa \mathrm{B}$ is suppressed by curcumin (diferuloylmethane)," The Journal of Biological Chemistry, vol. 270, pp. 24995-25000, 2005.

[111] S. M. Plummer, K. A. Holloway, M. M. Manson et al., "Inhibition of cyclo-oxygenase 2 expression in colon cells by the chemopreventive agent curcumin involves inhibition of NF- $\kappa \mathrm{B}$ activation via the NIK/IKK signalling complex," Oncogene, vol. 18, no. 44, pp. 6013-6020, 1999.

[112] M. S. Lan Li, B. B. Aggarwal, S. Shishodia, J. Abbruzzese, and R. Kurzrock, "Nuclear factor- $\kappa \mathrm{B}$ and $\mathrm{I} \kappa \mathrm{B}$ are constitutively active in human pancreatic cells, and their down-regulation by curcumin (Diferuloylmethane) is associated with the suppression of proliferation and the induction of apoptosis," Cancer, vol. 101, no. 10, pp. 2351-2362, 2004.

[113] A. B. Kunnumakkara, P. Diagaradjane, P. Anand et al., "Curcumin sensitizes human colorectal cancer to capecitabine by modulation of cyclin D1, COX-2, MMP-9, VEGF and CXCR4 expression in an orthotopic mouse model," International Journal of Cancer, vol. 125, no. 9, pp. 2187-2197, 2009.

[114] S. T. Tharakan, T. Inamoto, B. Sung, B. B. Aggarwal, and A. M. Kamat, "Curcumin potentiates the antitumor effects of gemcitabine in an orthotopic model of human bladder cancer through suppression of proliferative and angiogenic biomarkers," Biochemical Pharmacology, vol. 79, no. 2, pp. 218228, 2010.

[115] R. Wilken, M. S. Veena, M. B. Wang, and E. S. Srivatsan, "Curcumin: a review of anti-cancer properties and therapeutic activity in head and neck squamous cell carcinoma," Molecular Cancer, vol. 10, article 12, 2011.

[116] A. Kumar, S. Dhawan, N. J. Hardegen, and B. B. Aggarwal, "Curcumin (diferuloylmethane) inhibition of tumor necrosis factor (TNF)- mediated adhesion of monocytes to endothelial cells by suppression of cell surface expression of adhesion molecules and of nuclear factor- $\kappa \mathrm{B}$ activation," Biochemical Pharmacology, vol. 55, no. 6, pp. 775-783, 1998.

[117] M.-H. Pan, S.-Y. Lin-Shiau, and J.-K. Lin, "Comparative studies on the suppression of nitric oxide synthase by curcumin and its hydrogenated metabolites through down-regulation of $\mathrm{I} \kappa \mathrm{B}$ kinase and $\mathrm{NF} \kappa \mathrm{B}$ activation in macrophages," Biochemical Pharmacology, vol. 60, no. 11, pp. 1665-1676, 2000.

[118] F. Zhang, N. K. Altorki, J. R. Mestre, K. Subbaramaiah, and A. J. Dannenberg, "Curcumin inhibits cyclooxygenase-2 transcription in bile acid- and phorbol ester-treated human gastrointestinal epithelial cells," Carcinogenesis, vol. 20, no. 3, pp. 445-451, 1999.

[119] M. K. Jang, D. H. Sohn, and J.-H. Ryu, "A curcuminoid and sesquiterpenes as inhibitors of macrophage TNF- $\alpha$ release from Curcuma zedoaria," Planta Medica, vol. 67, no. 6, pp. 550-552, 2001.

[120] D. J. Slamon, W. Godolphin, L. A. Jones et al., "Studies of the HER-2/neu proto-oncogene in human breast and ovarian cancer," Science, vol. 244, no. 4905, pp. 707-712, 1989.

[121] K. Sato, M. Moriyama, S. Mori et al., "An immunohistologic evaluation of c-erbB-2 gene product in patients with urinary bladder carcinoma," Cancer, vol. 70, pp. 2493-2499, 1992. 
[122] J. Avruch, D. Zhou, and N. Bardeesy, "YAP oncogene overexpression supercharges colon cancer proliferation," Cell Cycle, vol. 11, no. 6, pp. 1090-1096, 2012.

[123] M. H. Elamin, Z. Shinwari, S.-F. Hendrayani et al., "Curcumin inhibits the sonic hedgehog signaling pathway and triggers apoptosis in medulloblastoma cells," Molecular Carcinogenesis, vol. 49, no. 3, pp. 302-314, 2010.

[124] P. Limtrakul, S. Anuchapreeda, S. Lipigorngoson, and F. W. Dunn, "Inhibition of carcinogen induced c-Ha-ras and cfos proto-oncogenes expression by dietary curcumin," $B M C$ Cancer, vol. 1, article 1, 2001.

[125] D.-W. Seol, Q. Chen, and R. Zarnegar, "Transcriptional activation of the hepatocyte growth factor receptor (c-met) gene by its ligand (hepatocyte growth factor) is mediated through AP1," Oncogene, vol. 19, no. 9, pp. 1132-1137, 2000.

[126] M. L. Y. Bangaru, S. Chen, J. Woodliff, and S. Kansra, "Curcumin (diferuloylmethane) induces apoptosis and blocks migration of human medulloblastoma cells," Anticancer Research, vol. 30, no. 2, pp. 499-504, 2010.

[127] A. Chen, J. Xu, and A. C. Johnson, "Curcumin inhibits human colon cancer cell growth by suppressing gene expression of epidermal growth factor receptor through reducing the activity of the transcription factor Egr-1," Oncogene, vol. 25, no. 2, pp. 278-287, 2006.

[128] L. Korutla, J. Y. Cheung, J. Mendelsohn, and R. Kumar, "Inhibition of ligand-induced activation of epidermal growth factor receptor tyrosine phosphorylation by curcumin," Carcinogenesis, vol. 16, no. 8, pp. 1741-1745, 1995.

[129] T. Dorai, N. Gehani, and A. Katz, "Therapeutic potential of curcumin in human prostate cancer. II. Curcumin inhibits tyrosine kinase activity of epidermal growth factor receptor and depletes the protein," Molecular Urology, vol. 4, no. 1, pp. 1-6, 2000.

[130] R.-L. Hong, W. H. Spohn, and M.-C. Hung, "Curcumin inhibits tyrosine kinase activity of p185(neu) and also depletes p185(neu1)," Clinical Cancer Research, vol. 5, no. 7, pp. 1884-1891, 1999.

[131] L. Camacho-Barquero, I. Villegas, J. M. Sánchez-Calvo et al., "Curcumin, a Curcuma longa constituent, acts on MAPK p38 pathway modulating COX-2 and iNOS expression in chronic experimental colitis," International Immunopharmacology, vol. 7, no. 3, pp. 333-342, 2007.

[132] Y. Wu, Y. Chen, J. Xu, and L. Lu, "Anticancer activities of curcumin on human Burkitt's lymphoma," Zhonghua Zhong Liu Za Zhi, vol. 24, no. 4, pp. 348-352, 2002.

[133] N. Diaz, S. Minton, C. Cox et al., "Activation of Stat3 in primary tumors from high-risk breast cancer patients is associated with elevated levels of activated Src and survivin expression," Clinical Cancer Research, vol. 12, no. 1, pp. 20-28, 2006.

[134] D. Germain and D. A. Frank, "Targeting the cytoplasmic and nuclear functions of signal transducers and activators of transcription 3 for cancer therapy," Clinical Cancer Research, vol. 13, no. 19, pp. 5665-5669, 2007.

[135] L. Lin, S. Deangelis, E. Foust et al., "A novel small molecule inhibits STAT3 phosphorylation and DNA binding activity and exhibits potent growth suppressive activity in human cancer cells," Molecular Cancer, vol. 9, article 217, 2010.

[136] W. Glienke, L. Maute, J. Wicht, and L. Bergmann, "Curcumin inhibits constitutive STAT3 phosphorylation in human pancreatic cancer cell lines and downregulation of survivin/BIRC5 gene expression," Cancer Investigation, vol. 28, no. 2, pp. 166171, 2010.
[137] M. G. Alexandrow, L. J. Song, S. Altiok, J. Gray, E. B. Haura, and N. B. Kumar, "Curcumin: a novel Stat3 pathway inhibitor for chemoprevention of lung cancer," European Journal of Cancer Prevention, vol. 21, no. 5, pp. 407-412, 2012.

[138] A. Jacob, R. Wu, M. Zhou, and P. Wang, "Mechanism of the antiinflammatory effect of curcumin: PPAR- $\gamma$ activation," PPAR Research, vol. 2007, Article ID 89369, 5 pages, 2007.

[139] J. Xu, Y. Fu, and A. Chen, "Activation of peroxisome proliferatoractivated receptor- $\gamma$ contributes to the inhibitory effects of curcumin on rat hepatic stellate cell growth," The American Journal of Physiology-Gastrointestinal and Liver Physiology, vol. 285, no. 1, pp. G20-G30, 2003.

[140] Y. Zhou, S. Zheng, J. Lin, Q.-J. Zhang, and A. Chen, "The interruption of the PDGF and EGF signaling pathways by curcumin stimulates gene expression of PPAR $\gamma$ in rat activated hepatic stellate cell in vitro," Laboratory Investigation, vol. 87, no. 5, pp. 488-498, 2007.

[141] A. Chen and J. Xu, "Activation of PPAR $\gamma$ by curcumin inhibits Moser cell growth and mediates suppression of gene expression of cyclin D1 and EGFR," American Journal of Physiology: Gastrointestinal and Liver Physiology, vol. 288, no. 3, pp. G447G456, 2005.

[142] M. D. Sternlicht and Z. Werb, "How matrix metalloproteinases regulate cell behavior," Annual Review of Cell and Developmental Biology, vol. 17, pp. 463-516, 2001.

[143] M. Egeblad and Z. Werb, "New functions for the matrix metalloproteinases in cancer progression," Nature Reviews Cancer, vol. 2, no. 3, pp. 161-174, 2002.

[144] C. C. Lynch and L. M. Matrisian, "Matrix metalloproteinases in tumor-host cell communication," Differentiation, vol. 70, no. 910, pp. 561-573, 2002.

[145] B. Fingleton, "Matrix metalloproteinases: roles in cancer and metastasis," Frontiers in Bioscience, vol. 11, no. 1, pp. 479-491, 2006.

[146] R. Fridman, M. Toth, D. Pena, and S. Mobashery, "Activation of progelatinase B (MMP-9) by gelatinase A (MMP-2)," Cancer Research, vol. 55, no. 12, pp. 2548-2555, 1995.

[147] S. K. Kim, Y. W. Kim, H. J. Youn, and S. H. Jung, "Curcumin suppresses MMP-9 expression via inhibition of PKCa/MAPKs and NF-B/AP-1 activation," Cancer Research, vol. 72, 2012.

[148] M.-S. Woo, S.-H. Jung, S.-Y. Kim et al., "Curcumin suppresses phorbol ester-induced matrix metalloproteinase- 9 expression by inhibiting the PKC to MAPK signaling pathways in human astroglioma cells," Biochemical and Biophysical Research Communications, vol. 335, no. 4, pp. 1017-1025, 2005.

[149] B. B. Aggarwal, S. Shishodia, Y. Takada et al., "Curcumin suppresses the paclitaxel-induced nuclear factor- $\kappa \mathrm{B}$ pathway in breast cancer cells and inhibits lung metastasis of human breast cancer in nude mice," Clinical Cancer Research, vol. 11, no. 20, pp. 7490-7498, 2005.

[150] Z. K. Hassan and M. H. Daghestani, "Curcumin effect on MMPs and TIMPs genes in a breast cancer cell line," Asian Pacific Journal of Cancer Prevention, vol. 13, no. 7, pp. 3259-3264, 2012.

[151] K. W. Lee, J.-H. Kim, H. J. Lee, and Y.-J. Surh, "Curcumin inhibits phorbol ester-induced up-regulation of cyclooxygenase- 2 and matrix metalloproteinase- 9 by blocking ERK1/2 phosphorylation and NF- $\kappa \mathrm{B}$ transcriptional activity in MCF10A human breast epithelial cells," Antioxidants and Redox Signaling, vol. 7, no. 11-12, pp. 1612-1620, 2005.

[152] A.-L. Chen, C.-H. Hsu, J.-K. Lin et al., "Phase I clinical trial of curcumin, a chemopreventive agent, in patients with high-risk 
or pre-malignant lesions," Anticancer Research, vol. 21, no. 4B, pp. 2895-2900, 2001.

[153] R. A. Sharma, H. R. McLelland, K. A. Hill et al., "Pharmacodynamic and pharmacokinetic study of oral Curcuma extract in patients with colorectal cancer," Clinical Cancer Research, vol. 7, no. 7, pp. 1894-1900, 2001.

[154] K. Polasa, T. C. Raghuram, T. P. Krishna, and K. Krishnaswamy, "Effect of turmeric on urinary mutagens in smokers," Mutagenesis, vol. 7, no. 2, pp. 107-109, 1992.

[155] S. G. Kim, M. S. Veena, S. K. Basak et al., "Curcumin treatment suppresses IKK $\beta$ kinase activity of salivary cells of patients with head and neck cancer: a pilot study," Clinical Cancer Research, vol. 17, no. 18, pp. 5953-5961, 2011.

[156] M. Kanai, K. Yoshimura, M. Asada et al., "A phase I/II study of gemcitabine-based chemotherapy plus curcumin for patients with gemcitabine-resistant pancreatic cancer," Cancer Chemotherapy and Pharmacology, vol. 68, no. 1, pp. 157-164, 2011.

[157] G. Garcea, D. P. Berry, D. J. L. Jones et al., "Consumption of the putative chemopreventive agent curcumin by cancer patients: assessment of curcumin levels in the colorectum and their pharmacodynamic consequences," Cancer Epidemiology, Biomarkers \& Prevention, vol. 14, no. 1, pp. 120-125, 2005.

[158] M. Majeed, V. Badmaev, U. Shivakumar, and R. Rajendran, Curcuminoids. Antioxidant Phytonutrients, Nutriscience, Piscataway, NJ, USA, 1995.

[159] K. B. Soni and R. Kuttan, "Effect of oral curcumin administration on serum peroxides and cholesterol levels in human volunteers," Indian Journal of Physiology and Pharmacology, vol. 36, no. 4, pp. 273-275, 1992.

[160] N. Dhillon, B. B. Aggarwal, R. A. Newman et al., "Phase II trial of curcumin in patients with advanced pancreatic cancer," Clinical Cancer Research, vol. 14, no. 14, pp. 4491-4499, 2008.

[161] R. Epelbaum, M. Schaffer, B. Vizel, V. Badmaev, and G. BarSela, "Curcumin and gemcitabine in patients with advanced pancreatic cancer," Nutrition and Cancer, vol. 62, no. 8, pp. 11371141, 2010.

[162] S. V. Kandarkar, S. S. Sawant, A. D. Ingle, S. S. Deshpande, and G. B. Maru, "Subchronic oral hepatotoxicity of turmeric in mice-histopathological and ultrastructural studies," Indian Journal of Experimental Biology, vol. 36, no. 7, pp. 675-679, 1998.

[163] R. A. Sharma, S. A. Euden, S. L. Platton et al., "Phase I clinical trial of oral curcumin: biomarkers of systemic activity and compliance," Clinical Cancer Research, vol. 10, no. 20, pp. 68476854, 2004.

[164] P. Anand, A. B. Kunnumakkara, R. A. Newman, and B. B. Aggarwal, "Bioavailability of curcumin: problems and promises," Molecular Pharmaceutics, vol. 4, no. 6, pp. 807-818, 2007.

[165] H. Shibata, H. Yamakoshi, A. Sato et al., "Newly synthesized curcumin analog has improved potential to prevent colorectal carcinogenesis in vivo," Cancer Science, vol. 100, no. 5, pp. 956960, 2009.

[166] L. Cen, B. Hutzen, S. Ball et al., "New structural analogues of curcumin exhibit potent growth suppressive activity in human colorectal carcinoma cells," BMC Cancer, vol. 9, article 99, 2009.

[167] J. Bromberg, M. Wrzeszczynska, G. Devgan et al., "Stat3 as an oncogene," Cell, vol. 98, pp. 295-303, 1999.

[168] T. Gritsko, A. Williams, J. Turkson et al., "Persistent activation of Stat3 signaling induces survivin gene expression and confers resistance to apoptosis in human breast cancer cells," Clinical Cancer Research, vol. 12, no. 1, pp. 11-19, 2006.
[169] M. M. Yallapu, M. R. Dobberpuhl, D. M. Maher, M. Jaggi, and S. C. Chauhan, "Design of curcumin loaded cellulose nanoparticles for prostate cancer," Current Drug Metabolism, vol. 13, no. 1, pp. 120-128, 2012.

[170] L. Lin, Y. Liu, H. Li et al., "Targeting colon cancer stem cells using a new curcumin analogue, GO-Y030," British Journal of Cancer, vol. 105, no. 2, pp. 212-220, 2011.

[171] C. Kudo, H. Yamakoshi, A. Sato et al., "Novel curcumin analogs, GO-Y030 and GO-Y078, are multitargeted agents with enhanced abilities for multiple myeloma," Anticancer Research, vol. 31, no. 11, pp. 3719-3726, 2011.

[172] B. Hutzen, L. Friedman, M. Sobo et al., "Curcumin analogue GO-Y030 inhibits STAT3 activity and cell growth in breast and pancreatic carcinomas," International Journal of Oncology, vol. 35, no. 4, pp. 867-872, 2009.

[173] L. Lin, B. Hutzen, S. Ball et al., "New curcumin analogues exhibit enhanced growth-suppressive activity and inhibit AKT and signal transducer and activator of transcription 3 phosphorylation in breast and prostate cancer cells," Cancer Science, vol. 100, no. 9, pp. 1719-1727, 2009.

[174] M. Pisano, G. Pagnan, M. A. Dettori et al., "Enhanced antitumor activity of a new curcumin-related compound against melanoma and neuroblastoma cells," Molecular Cancer, vol. 9, article 137, 2010.

[175] T. J. Somers-Edgar, S. Taurin, L. Larsen, A. Chandramouli, M. A. Nelson, and R. J. Rosengren, "Mechanisms for the activity of heterocyclic cyclohexanone curcumin derivatives in estrogen receptor negative human breast cancer cell lines," Investigational New Drugs, vol. 29, no. 1, pp. 87-97, 2011.

[176] B. Yadav, S. Taurin, L. Larsen, and R. J. Rosengren, "RL66 a second-generation curcumin analog has potent in vivo and in vitro anticancer activity in ER-negative breast cancer models," International Journal of Oncology, vol. 41, no. 5, pp. 1723-1732, 2012.

[177] A. L. Kasinski, Y. Du, S. L. Thomas et al., "Inhibition of $\mathrm{I} \kappa \mathrm{B}$ kinase-nuclear factor- $\kappa \mathrm{B}$ signaling pathway by 3,5-bis(2flurobenzylidene)piperidin-4-one (EF24), a novel monoketone analog of curcumin?" Molecular Pharmacology, vol. 74, no. 3, pp. 654-661, 2008.

[178] E. M. Al-Hujaily, A. G. Mohamed, I. Al-Sharif et al., "PAC, a novel curcumin analogue, has anti-breast cancer properties with higher efficiency on ER-negative cells," Breast Cancer Research and Treatment, vol. 128, no. 1, pp. 97-107, 2011.

[179] B. Wahlstr, G. Blennow, and B. Wahlström, "A study on the fate of curcumin in the rat," Acta pharmacologica et toxicologica, vol. 43, pp. 86-92, 1978.

[180] K.-Y. Yang, L.-C. Lin, T.-Y. Tseng, S.-C. Wang, and T.-H. Tsai, "Oral bioavailability of curcumin in rat and the herbal analysis from Curcuma longa by LC-MS/MS," Journal of Chromatography B: Analytical Technologies in the Biomedical and Life Sciences, vol. 853, no. 1-2, pp. 183-189, 2007.

[181] G. Shoba, D. Joy, T. Joseph, M. Majeed, R. Rajendran, and P. S. S. R. Srinivas, "Influence of piperine on the pharmacokinetics of curcumin in animals and human volunteers," Planta Medica, vol. 64, no. 4, pp. 353-356, 1998.

[182] S. Bisht and A. Maitra, "Systemic delivery of curcumin: 21st century solutions for an ancient conundrum," Current Drug Discovery Technologies, vol. 6, pp. 192-199, 2009.

[183] J. Shaikh, D. D. Ankola, V. Beniwal, D. Singh, M. N. V. Ravi Kumar, and J. Pharm, "Nanoparticle encapsulation improves oral bioavailability of curcumin by at least 9 -fold when compared to curcumin administered with piperine as absorption 
enhancer," European Journal of Pharmaceutical Sciences, vol. 37, pp. 223-230, 2009.

[184] M. Takahashi, S. Uechi, K. Takara, Y. Askin, K. Wada, and J. Agric, "Evaluation of an oral carrier system in rats: bioavailability and antioxidant properties of liposome-encapsulated curcumin," Journal of Agricultural and Food Chemistry, vol. 57, pp. 9141-9146, 2009.

[185] S. Onoue, H. Takanashi, Y. Kawabata et al., "Formulation design and photochemical studies on nanocrystal solid dispersion of curcumin with improved oral bioavailability," Journal of Pharmaceutical Sciences, vol. 99, pp. 1871-1881, 2009.

[186] B. Antony, B. Merina, V. Iyer, N. Judy, K. Lennertz, and S. Joyal, "A pilot cross-over study to evaluate human oral bioavailability of BCM-95 CG (Biocurcumax), a novel bioenhanced preparation of curcumin," Indian Journal of Pharmaceutical Sciences, vol. 70, no. 4, pp. 445-449, 2008.

[187] H. Sasaki, Y. Sunagawa, K. Takahashi et al., "Innovative preparation of curcumin for improved oral bioavailability," Biological and Pharmaceutical Bulletin, vol. 34, no. 5, pp. 660-665, 2011.

[188] M. Kanai, A. Imaizumi, Y. Otsuka et al., "Dose-escalation and pharmacokinetic study of nanoparticle curcumin, a potential anticancer agent with improved bioavailability, in healthy human volunteers," Cancer Chemotherapy and Pharmacology, vol. 69, no. 1, pp. 65-70, 2012.

[189] V. Gupta, A. Aseh, C. N. Ríos, B. B. Aggarwal, and A. B. Mathur, "Fabrication and characterization of silk fibroin-derived curcumin nanoparticles for cancer therapy," International Journal of Nanomedicine, vol. 4, pp. 115-122, 2009.

[190] S. S. Dhule, P. Penfornis, T. Frazier et al., "Curcumin-loaded $\gamma$-cyclodextrin liposomal nanoparticles as delivery vehicles for osteosarcoma," Nanomedicine, vol. 8, no. 4, pp. 440-451, 2012.

[191] J. Shaikh, D. D. Ankola, V. Beniwal, D. Singh, and M. N. V. R. Kumar, "Nanoparticle encapsulation improves oral bioavailability of curcumin by at least 9-fold when compared to curcumin administered with piperine as absorption enhancer," European Journal of Pharmaceutical Sciences, vol. 37, no. 3-4, pp. 223-230, 2009.

[192] L. Li, B. Ahmed, K. Mehta, and R. Kurzrock, "Liposomal curcumin with and without oxaliplatin: effects on cell growth, apoptosis, and angiogenesis in colorectal cancer," Molecular Cancer Therapeutics, vol. 6, no. 4, pp. 1276-1282, 2007.

[193] D. Guzman-Villanueva, I. M. El-Sherbiny, D. Herrera-Ruiz, and H. D. C. Smyth, "Design and in vitro evaluation of a new nanomicroparticulate system for enhanced aqueous-phase solubility of curcumin," BioMed Research International, vol. 2013, Article ID 724763, 9 pages, 2013.

[194] X. Xie, Q. Tao, Y. Zou et al., "PLGA nanoparticles improve the oral bioavailability of curcumin in rats: characterizations and mechanisms," Journal of Agricultural and Food Chemistry, vol. 59, no. 17, pp. 9280-9289, 2011.

[195] S. Prasad, A. K. Tyagi, and B. B. Aggarwal, "Recent developments in delivery, bioavailability, absorption and metabolism of curcumin: the golden pigment from golden spice," Cancer Research and Treatment, vol. 46, pp. 2-18, 2014. 


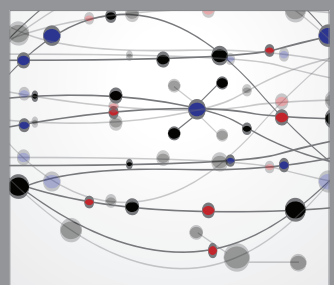

The Scientific World Journal
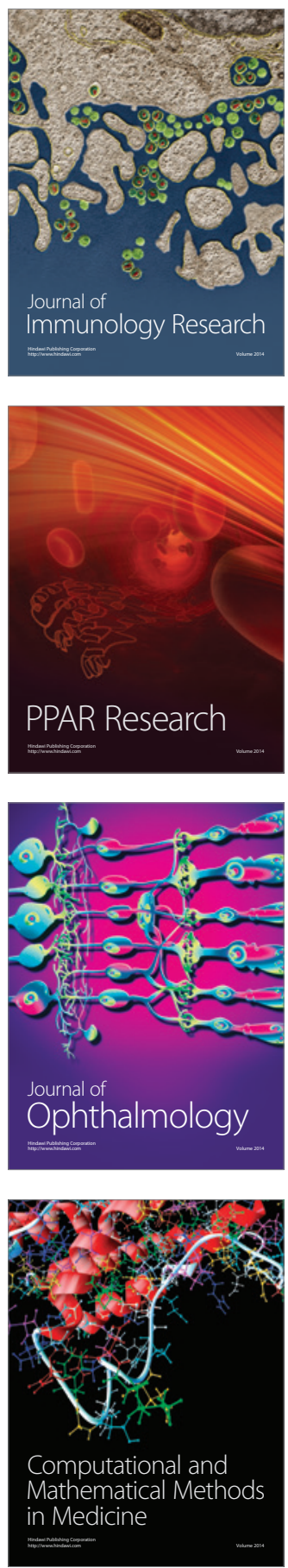

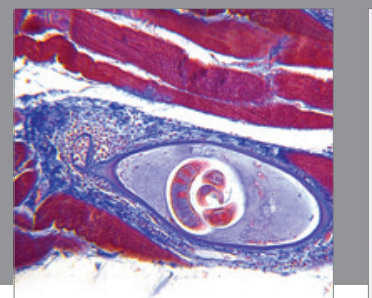

Gastroenterology

Research and Practice
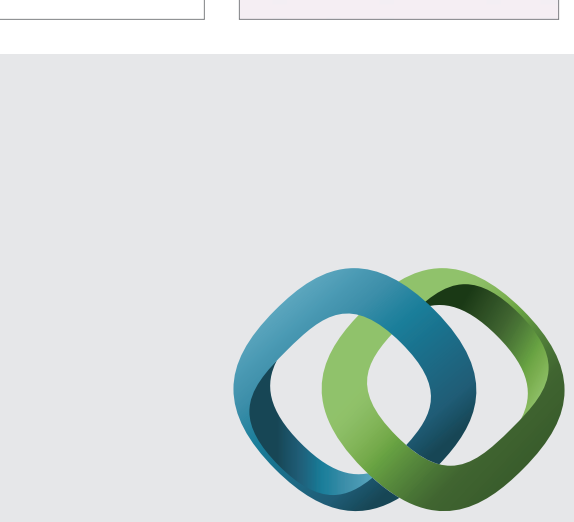

\section{Hindawi}

Submit your manuscripts at

http://www.hindawi.com
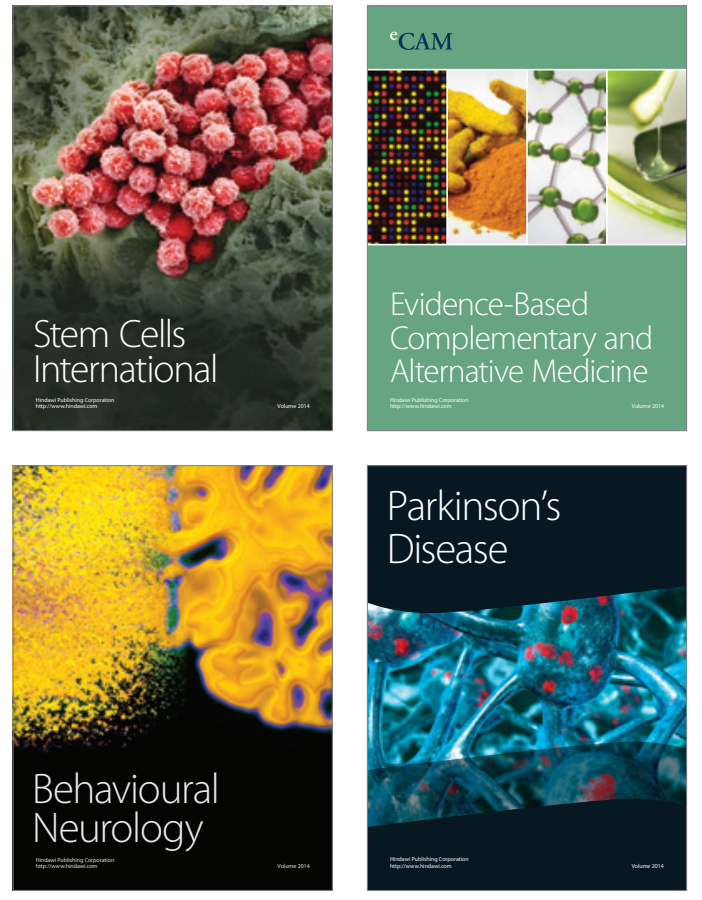
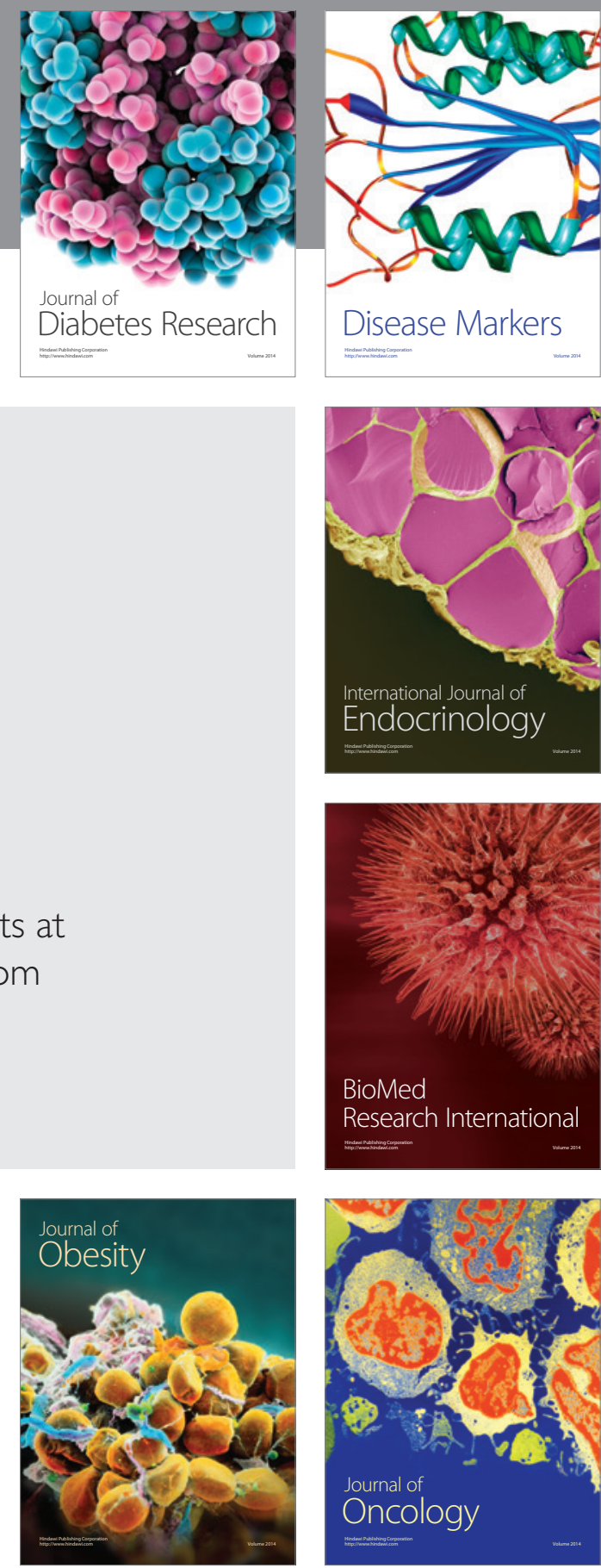

Disease Markers
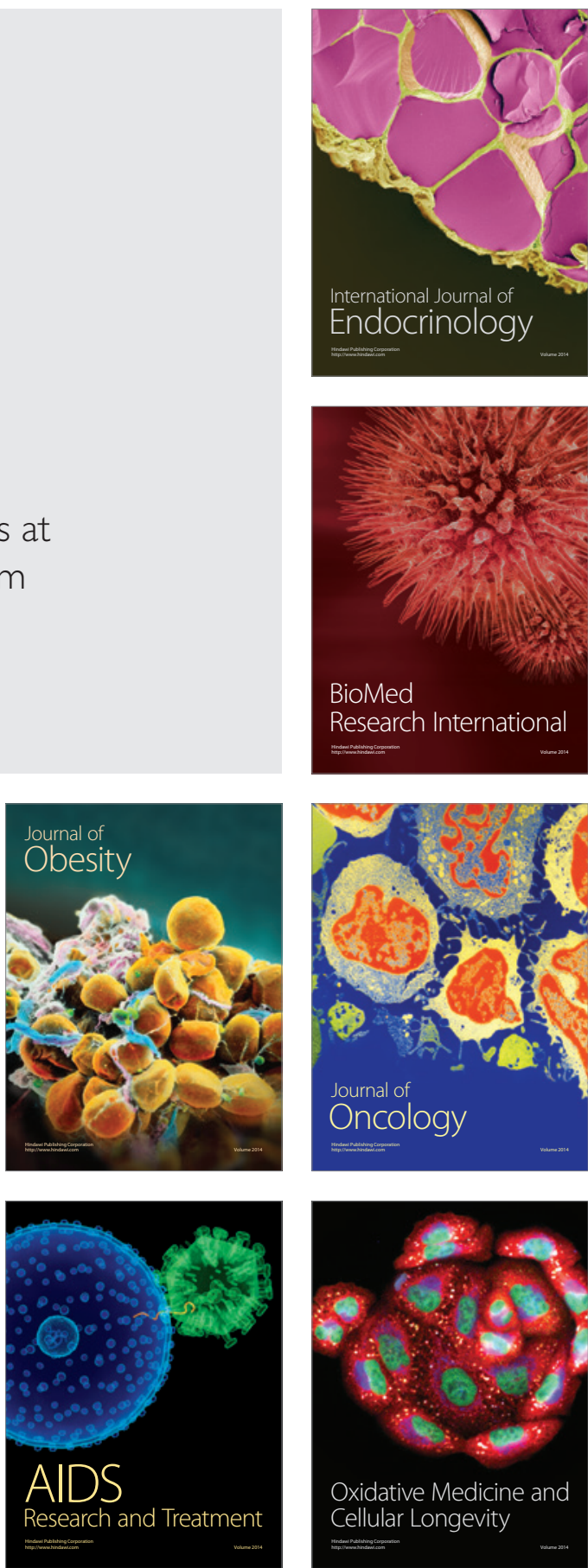